\title{
Cultivating the dry forests of South America: Diversity of land users and imprints on ecosystem functioning
}

Germán Baldi ${ }^{1,{ }^{\star}}$, Javier Houspanossian ${ }^{1}$, Francisco Murray ${ }^{1,2}$, Adriel A. Rosales ${ }^{1,3}$, Carla V. Rueda $^{1,4}$, and Esteban G. Jobbágy ${ }^{1}$

Affiliation: ${ }^{1}$ Grupo de Estudios Ambientales - IMASL, Universidad Nacional de San Luis \& CONICET. Ejército de los Andes 950, D5700HHW. San Luis, Argentina. ${ }^{2}$ INTA, EEA Valle Inferior. Ruta Nacional № 3 km 971, camino 4, 8500. Viedma, Argentina. ${ }^{3}$ Universidad de La Punta. Av. Universitaria s/n, D5710. La Punta, Argentina. ${ }^{4}$ Instituto de Silvicultura y Manejo de Bosques, Universidad Nacional de Santiago del Estero. Av. Belgrano 1912, G4200ABT. Santiago del Estero, Argentina.

* Corresponding author: Germán Baldi, Tel: +54-266-4424740 - Fax +54-266-4422803, baldi@unsl.edu.ar.

\section{Abstract}

In the South American dry forest of the Dry Chaco and Chiquitania, the area under cultivation rose from $10 \%$ to $19 \%$ over the last ten years, and little biophysical, economical, or political constrains seem to prevent further expansion. Although typically associated to a homogeneous agribusiness system, agriculture and its expansion in this territory involve a diverse array of land users. Here we (i) identified and mapped the most conspicuous groups of land users based on existing scientific literature and technical reports, and (ii) described their associated landscape pattern and (iii) vegetation functioning based on different remote sensing tools applied to a set of 218 sample points. We recognized 14 groups of land users of local or foreign origin, composed by individuals or corporative organizations, and dedicated either to pasture or crop production, or its combination. These groups displayed a wide variation in the scale of their operations as suggested by a 60 -fold difference in paddock sizes. Twelve years of MODISNDVI data showed small and non-significant differences in the magnitude of primary productivity (1.2 fold-difference) but strong contrasts in its seasonality and long-term variability, 
including shifts in the rates of vegetation greening and browning (up to 4 fold-differences), growing period length (193 to 278 days $y^{-1}$ ), number of cultivation seasons per year ( 1 to 1.75 ), and inter-annual coefficient of variation (up to 0.13). Agriculture under capitalized groups was characterized by very large paddocks, less stable productivity patterns, and more divergent seasonality. Instead, all smallholders showed more stable productivities both seasonally and inter-annually. Deforestation and cultivation in these dry regions does not have a single imprint on landscapes configuration and primary production dynamics, but one that shifts depending on the human and productive context under which they take place.

Keywords: Dry Chaco, Chiquitania, cultivation, rural typology, landscape pattern, vegetation functioning.

\section{Introduction}

Dry subtropical regions face a rapid expansion of agriculture over the still dominant areas of natural and seminatural vegetation (Miles et al., 2006; Portillo-Quintero and SánchezAzofeifa, 2010; Baldi and Jobbágy, 2012). Among the driving factors of these changes are the increasing overseas demand of food and fuel, the enhanced connectivity of formerly remote areas, more stable economies, and the release of local population from poverty and violence (Unruh, 1997; Redo et al., 2011). Agricultural land in these regions is managed by a broad array of users ranging from small-scale subsistence to large-scale commodity production, depending on the balance between population density, connectivity to global markets, and affluence/technology conditions (Grau et al., 2005b; Cotula et al., 2009; Lobell et al., 2010; Baldi and Jobbágy, 2012). Thus, the results of such transitions in terms of landscape pattern (rate of agricultural subdivision, paddocks shape), and of vegetation functioning (magnitude and temporal variability of primary productivity) may depend greatly on the human context under which changes occurs and not only on the biophysical conditions of the territory (Ellis and Ramankutty, 2008; Baldi et al., 2013).

In South America, the Dry Chaco and Chiquitania ecoregions do not escape from this general trend of expanding cultivation (Grau et al., 2005b; Killeen et al., 2007; Guyra Paraguay, 2013). Although it still represents one of the largest extents of subtropical dry forests in the 
world, its transformation become noteworthy at a regional scale since the beginning of the 1990's (van Dam, 2003; Adámoli et al., 2011; Leguizamón, 2014), both through the expansion of the few early (i.e. 1950's) agricultural foci and emerging new areas, where no large biophysical limitations seem to constrain their establishment (Ewel, 1999; Pacheco, 2006; Houspanossian et al., in preparation). The historical availability of federal lands, an ethnically and economically diverse population, governmental immigration campaigns, and a recent openness to the global market of agricultural goods, led to an exceptionally heterogeneous scenario of agricultural land users (Glatzle, 2004; Vázquez, 2006; Killeen et al., 2008; Redo, 2013). Under this complexity, local- to country-scale research showed a noticeable imprint on landscape composition and its dynamic (Killeen et al., 2008; Casco Verna, 2011).

In this territory, a developing body of studies is showing the effect of deforestation and subsequent cultivation on primary productivity patterns, carbon pools and emissions, groundwater hydrology, and climate regulation (Nitsch, 1995; Gasparri et al., 2008; Jobbágy et al., 2008; Santoni et al., 2010; Amdan et al., 2013; Houspanossian et al., 2013). In particular, cultivation introduces an amplification of the seasonal and inter-annual variability of productivity, apparently without changing its average magnitude (Volante et al., 2012; Baldi et al., 2013). However, little is known about the regional spatial and temporal heterogeneity of primary productivity patterns, and even less about its relationship with the diverse land management approaches performed by farmers and ranchers (Guerschman et al., 2003).

Our guiding questions are: Who are the agricultural land users in the Dry Chaco and Chiquitania territory? Users have a particular imprint on landscape patterns and vegetation functioning? Is there an interaction between this variable human context and aridity restrictions? To address these questions we (i) identify agricultural land users and characterize a series of social, operational, and productive traits from existing scientific literature and technical reports. Then we quantify (ii) the imprint of these groups on landscape patterns (i.e. paddock size and shape) using Google Earth high resolution imagery and (iii) their vegetation functioning (i.e. magnitude, and seasonal and long-term variability of primary productivity) using high temporal resolution MODIS spectral data. Finally, we (iv) assess the effect of climatic water availability on vegetation functioning patterns. While characterizing contrasts across the entire region, we 
make emphasis on the comparisons between neighbouring groups of land users (sharing presumably a same physical environment).

\section{Methods}

\subsection{Study area}

We focused our analyses on the dry portion of the Dry Chaco and Chiquitania territory (Fig. 1, left panel), encompassing an area of $775,000 \mathrm{~km}^{2}$ in Northern Argentina (40\%), Southeastern Bolivia (38\%), and Western Paraguay (22\%) according to Olson et al. limits (2001). The territory is characterized by an extremely flat relief, and by fertile and deep soils of quaternary origin (aeolian and fluvial). Rainfall follows a monsoonal pattern, ranging from 450 $\mathrm{mm}$ year $^{-1}$-in the north-center- up to $1,200 \mathrm{~mm}$ year $^{-1}$-in the outer limits-, and average temperatures from 20 to $25^{\circ} \mathrm{C}$ from south to north, according to the "Ten Minute Climatology database" (New et al., 2002). These two factors determine a general water deficit (especially from May to October). The ratio of mean annual precipitation-to-potential evapotranspiration (PPT:PET) ranges from 0.3 to 0.7 .

Originally composed of dry forests and savannas, natural vegetation has been subject to different uses including logging, charcoal extraction, and grazing, which led to changes in structure and composition (Morello et al., 2005; Adámoli et al., 2011; Gasparri and Baldi, 2013; Rueda et al., 2013). Currently a dominant, continuous, cover of woody vegetation characterize the area (Baldi et al., 2013), with agricultural areas reaching in March $201319 \%$ of the study area $(21,13$, and 25\% in Argentina, Bolivia and Paraguay; respectively) (Killeen et al., 2008; UMSEF, 2008; REDIEX, 2009; Vallejos et al., 2012; Volante et al., 2012; Guyra Paraguay, 2013). In Argentina and Bolivia agriculture is mainly devoted to the production of cereals, oil, and industrial crops (e.g. soy, wheat, cotton, and sunflower) or exotic pastures (e.g. Cenchrus ciliaris, Panicum spp.). This last use is dominant in Paraguay, were exotic (i.e. Leucaena leucocephala) and native shrubs (e.g. Prosopis spp.) are additional components of pastures (van Dam, 2003; Glatzle, 2004). 


\subsection{Agricultural land users}

In order to identify the different land users within the agricultural territory of Dry Chaco and Chiquitania (Fig. 1, left panel), we explored a set of 22 technical reports, papers, thesis, and websites dealing with local to regional agricultural production and expansion. Each of these sources of information described for widely accepted groups (e.g. ranching corporations), social (ethnic origin, settlement history, ownership), operational (source of capital, use of inputs, mechanization), and productive traits (crops vs. pastures, fate of products) -following Kostrowicki (1992)-. From the described dominant traits, and with the aid of local expertise and from our own knowledge, we generated a single scheme of groups by avoiding overlaps and inconsistencies. Due to the strength of political factors driving land use in the region (Vázquez, 2007; Redo et al., 2011; Leguizamón, 2014), we further distinguished groups by country. Though we acknowledge that some unmanaged variability within groups may exist, quantitative information at a paddock level is not currently available for the entire region.

-Insert Fig. 1 here-

\subsection{Sampling scheme}

Spatiality explicit location of the different agricultural land users groups was available in 12 of the 22 bibliographic information sources. The spatial accuracy and the extent of this information varied from sketches (e.g. Vázquez, 2007) to detailed maps (e.g. DGEEC, 2004), and from very small (e.g. Arístide, 2009) to large areas (e.g. Killeen et al., 2008), respectively. This information encompassed the entire Bolivian territory, almost two-thirds of Paraguay, and scattered areas throughout Argentina. Within these areas allocated to different agricultural land users, we determined a variable number of sample points for each group in order to characterize landscape patterns and vegetation functioning. The number of sample points depended on the known extent of each group, and on the accomplishment of points of the following criteria: (i) be composed by $>95 \%$ of crops or pastures within a 250 m-radius area (the remaining area being woody corridors or isolated trees), (ii) be $>3 \mathrm{~km}$ away from any other sample point (with the exception of Argentinean Mennonites due to their reduced territorial extent), and (iii) be subject to cultivation since 2000 or earlier. We set a maximum of 25 points 
per group, discarding extra sites through a random selection process, resulting in the 218 selected samples. The first two conditions were evaluated by a visual inspection of very high $(\leq 1$ m, Quickbird) to high (2.5 to $10 \mathrm{~m}$, Spot) spatial resolution images from Google Earth (http://www.google.com/earth/index.html). The third condition was evaluated by a visual inspection of imagery circa 2000 from the "GeoCover" Orthorectified Landsat ETM+ Mosaics project (MDA Federal, 2004), and several existing land cover / land use classifications (Huang et al., 2009; Consorcio L. Berger - ICASA, 2010; Casco Verna, 2011; Vallejos et al., 2012; Volante et al., 2012). Agricultural paddocks were easily recognizable from the uncultivated surrounds by their relatively high brightness and regular shape (Clark et al., 2010; Baldi et al., 2013). For functioning analyses we considered only those samples with continuous agricultural areas of $>10$ ha (two MOD13Q1 pixels, 213 sample points) in order to avoid signal contamination from uncultivated areas. Finally, the group of Paraguayan campesinos was discarded from the analyses due to an undetermined location and minor extension, while the group of Bolivian local indigenous was only analysed for landscape patterns due to the very small size and isolation of its agricultural paddocks (Killeen et al., 2008).

\subsection{Landscape pattern}

For each individual sample point we digitalized the contours of its corresponding paddock and the 8 contiguous ones. An "on-screen" visual interpretation of the Google Earth images was applied. Paddocks were individualized from each other according to differences in colour and texture, and to the presence of physical barriers (wind-breaks, roads, water channels, etc.). We selected the newest available imagery at the time of sampling (2012). For each sample point we obtained the (i) mean and (ii) maximum paddock size, (iii) a mean elongation index given by the ratio of major-to-minor side of the paddocks, and (iv) a mean shape index given by the perimeter-to-area ratio relative to a circular standard. Last two metrics equal 1 when all paddocks are square or circles, and increases without limit as the shape becomes less symmetric (McGarigal and Marks, 1995). Additionally, we performed a qualitative description about the most frequent degree of paddock aggregation (isolated vs. clustered) and spatial arrangement (scattered, consolidated, radial, fishbone) of landscapes within a $3 \mathrm{~km}$ radius area around sample points. 


\subsection{Vegetation functioning}

In order to evaluate differences in the magnitude, seasonality, and long-term variability of primary productivity across agricultural land users, we applied 19 metrics based on temporal series of Normalized Difference Vegetation Index (NDVI) for 2000-2011 (Monteith, 1981; Paruelo and Lauenroth, 1995; Jobbágy et al., 2002) (Table 2). For each of the 213 sample points we downloaded NDVI data from the Terra MODIS instrument (MOD13Q1; spatial and temporal resolutions of $250 \mathrm{~m}$ and 16 days, respectively) from the ORNL "MODIS Global Subsets: Data Subsetting and Visualization" on-line tool (http://daac.ornl.gov). For calculations, we defined growing years from September to August. For each sample point we only considered NDVI values with highest quality (flagged as category VI, $79 \%$ of the data) (Huete et al., 2002), eliminating noise from clouds and aerosols. We used the code TIMESAT v.3.1. to reconstruct temporal series (Jönsson and Eklundh, 2002; Jönsson and Eklundh, 2004; Eklundh and Jönsson, 2011). This tool fits smoothed model functions that capture one or two cycles of growth and decline per year. We selected an adaptative Savitzky-Golay model (Jönsson and Eklundh, 2002), assuming a preliminary bi-modal seasonality. From the reconstructed temporal series, we calculated the metrics by means of TIMESAT and the R v.2.15 statistical software. Metrics 1 to 12 (Table 2) were calculated by averaging annual measures of magnitude and seasonality, whereas metrics 13 to 16 considered their inter-annual variability. Metrics 17 to 19 quantified the contribution of three additive temporal components to the overall variance of NDVI. With the aim of assessing whether the groups have significant differences in terms of vegetation functioning (and spatial configuration), we applied non-parametric Kruskal-Wallis' $H$ and post hoc comparison tests (Conover, 1999).

-Insert Table 2 here-

After calculating the 19 functioning metrics, we explored their reciprocal associations using Kendall's T non-parametric correlation test (Whittaker, 1987). Then, in order to identify major functioning patterns, we ordered samples based on the Reciprocal Averaging (RA) method (Legendre and Legendre, 1998). Instead of maximizing the entire variation proportion 
that can be explained by single axes (as in Principal Component Analysis), RA maximizes the correlation between the descriptive variables (functioning metrics) and the score assigned to samples (Nenadić and Greenacre, 2007). The eigenvalue associated with each axis can be interpreted as the correlation coefficient between metric and sample scores, and its ratio over the total variance of the data matrix, known as "inertia", represents its explanatory power. We explored differences among agricultural land users within the RA space by (i) plotting the centroid and variability (one standard deviation) of each group within the RA space and (ii) applying a Multi-Response Permutation Procedure (MRPP, see details in Supplementary material) (Biondini et al., 1988). To achieve a graphic representation of the mean seasonal curves, we averaged for each group the reconstructed NDVI values of the 23 dates that MOD13Q1 provides by year for the temporal series of 12 years. In contrast to the metrics described above, which were calculated for each sample point, these curves reflect the spatially aggregated seasonality of each agricultural land user.

In order to explore to what extent water availability gradients -within the study area-are more important than or interact with agricultural land users shaping vegetation functioning, we evaluated the association between the functioning metrics and the mean precipitation-topotential evapotranspiration ratio (PPT:PET). This measure was based on averaged-monthly data (1961-1990 period) from the "Ten Minute Climatology data base" (New et al., 2002); PET was retrieved from the Penman-Monteith equation (Allen et al., 2004). Linear regression models were applied to the entire data set and to individual group.

\section{Results}

\subsection{Agricultural land users}

Fourteen groups of agricultural land users were delimitated across the Dry Chaco and Chiquitania territory, 6 of them in Bolivia, 5 in Paraguay, and 3 in Argentina (Table 1; Fig. 1, right panels). These groups were settled during different periods and have a very diverse ethnic origin (e.g. indigenous or Brazilian in Paraguay), are composed by individuals or corporative organizations, have contrasting sources of capital or production fates (local to international), among other differences. Additionally, they represent a variable fraction of the current 
agricultural territory (e.g. 100 vs. $11,000 \mathrm{~km}^{2}$ for Mennonite colonists in Argentina and Paraguay, respectively), with also variable expansion rates (up to $1,000 \mathrm{~km}^{2} \mathrm{y}^{-1}$ for Farming corporations \& capitalized farmers in Argentina).

-Insert Table 1 here-

\subsection{Landscape pattern}

The diversity of agricultural land users led to a large heterogeneity of landscapes (Fig. 2 and Table I, Supplementary material). Corporations and capitalized individuals, even though oriented to farming or ranching activities, had the largest scale of production across the three countries (mean and largest paddock size values $>50 \mathrm{ha}$ ). On the opposite extreme, local indigenous in Bolivia and Paraguay showed the smallest scale (mean paddock size $<3.8$ ha). Thereby, a 60-fold difference was observed between extreme cases (farming corporations \& capitalized farmers in Argentina and local indigenous in Bolivia). Colonist groups (Andean indigenous, Japanese, Mennonite) showed intermediate scales (paddock size from 9.5 to 32.7 ha), with Mennonite ones showing important differences across countries (up to $\sim 3$ times between Paraguay and Argentina). In terms of paddocks shape, complexity was higher (elongation > 3.7, MSI values > 1.5) for Mennonite colonists in Argentina and Bolivia and Andean indigenous colonists in Bolivia, with paddocks conforming fishbone and radial clusters, respectively (Table I and Fig. I, Supplementary material). Shape complexity was lower for local indigenous in Bolivia and mixed and Brazilian ranching corporations in Paraguay, with isolated and symmetrical paddocks.

-Insert Fig. 2 here-

\subsection{Vegetation functioning}

Mean NDVI curves (Fig. 3), reflecting the spatially aggregated behaviour of each group of agricultural land users, showed much greater contrasts in seasonality than in the magnitude of primary productivity. Extreme seasonal patterns ranged from a single to two short growing 
periods with high maximum and low minimum values (e.g. farming corporations \& capitalized farmers in Argentina, Andean indigenous colonists in Bolivia), to a more evenly distributed growth throughout the year (e.g. all groups in Paraguay).

Individual metrics showed small differences in the magnitude of primary productivity (metrics 1 to 3 , Table 3 ), with mean NDVI ranging from 0.46 to 0.57 (1.2-fold variation) across agricultural land users. Bolivian groups (except Mennonite colonists) and Brazilian ranching corporations in Paraguay showed the highest mean values, while the remaining Paraguayan groups showed the lowest. All neighbouring groups (presumably under a similar climatic and soil context, Fig. 1) displayed strong convergences for this metric. Differences increased for maximum (1.4-fold), and minimum (1.5-fold) metrics. Farming corporations \& capitalized farmers in Argentina and Andean indigenous colonists in Bolivia showed the highest values for NDVI maximum (> 0.83), while the first group and the Mennonite colonists in Paraguay, the lowest for NDVI minimum $(<0.25)$.

Seasonal patterns (metrics 4 to 12, and 18; Table 3) showed the greatest differences across agricultural land users. Farming corporations \& capitalized farmers in Argentina and local indigenous in Paraguay had the highest and lowest range and inter-annual CV values, respectively (1.8 and 1.9-fold variation, respectively). These general variability metrics could be better understood by exploring the differences in the number of growing seasons, the length of the growing period, and the browning and greening rates. The number of growing seasons was $>1.25$ for three Bolivian and one Argentinean groups (reaching 1.75 for Andean indigenous colonists), while was $=1$ for all Paraguayan and for Mennonite colonists in Argentina. Farming corporations \& capitalized farmers in Argentina had the most acute peak around the mean, associated with high browning and greening rates (both metrics highly correlated; Fig. II, Supplementary material), and the shortest growing period (193 day $\left.y^{-1}\right), 40$ days $y^{-1}$ less than the neighbouring local campesinos. All Bolivian and Paraguayan groups (ranching and farmingoriented) exceeded the 220 day $y^{-1}$. In all cases, the seasonal contribution to the overall variance of NDVI time series exceeded trend and residual components (from 45 to $68 \%$ ).

Groups also differed in terms of the inter-annual NDVI variability (metrics 13 to 17 , Table 3). Mean and maximum coefficients of variation were highly correlated (Fig. II, Supplementary material) and were highest (i.e. least stable productivity) for mixed ranching 
corporations in Paraguay, all Mennonite colonists, and farming corporations \& capitalized farmers in Argentina. On the other hand, the lowest values (i.e. most stable productivity) were found for the Brazilian ranching corporations and local indigenous in Paraguay and the Andean indigenous colonists in Bolivia. In Paraguay, local indigenous showed more stable production than neighbouring Mennonite colonists and mixed ranching corporations.

-Insert Fig. 3 here-

-Insert Table 3 here-

The first two dimensions of the reciprocal averaging (RA) explained half of the functional variability of the Dry Chaco and Chiquitania agricultural territory. A first axis (34\% explained inertia) was related to the seasonality of samples, driven positively by browning and greening rates (and to a lesser extent peakness) and a negatively by the greening-to-browning ratio and the growing period (Fig. 4). A second axis (21.2\% explained inertia) was related to the inter-annual variability characteristics of samples, with a positive association with trend contribution and the mean and maximum NDVI variability. Remarkably, magnitude metrics (mean, maximum, and range) played a secondary role in the ordination of samples, with low eigenvalues for both ordination axes.

Even displaying some internal heterogeneity, each group could be described according to the specific location of its centroid within the multivariate space (Fig. 4a). Located towards the low end of the first RA axis, local indigenous and Brazilian and mixed ranching corporations in Paraguay had the flattest NDVI curves, while towards the high end, farming corporations and capitalized farmers in Argentina and Bolivia and the Andean indigenous colonists in Bolivia had the most symmetrical and acute curves. Located towards the low end of the second RA axis, Brazilian ranching corporations and local indigenous at Paraguay showed the most interannually stable patterns, while the opposite occurred with Mennonite colonists in Argentina and the rest of the users in Paraguay.

Neighbouring agricultural land users were not necessarily close in the ordination space, as shown by standard deviation ellipses (Fig. 4b-d) and MRRP (Table II, Supplementary material). In Argentina, local campesinos and farming corporations \& capitalized farmers arose 
as statistically different clusters. In Bolivia, Andean indigenous colonists differed significantly from local farmers and Mennonite colonists. In Paraguay, Mennonite colonists and mixed ranching corporations differed from local indigenous. Distant groups with preponderance of ranching activities showed some clustering along the first RA axis, whereas farming-oriented groups were more dispersed. Little clustering of groups according to ethnicity, settlement origin, and capitalization, were found.

-Insert Fig. 4 here-

In contrast with the strong links that agricultural land users had with the temporal variability of primary productivity, water availability (as described by the PPT:PET) resulted highly correlated with its average magnitude (Kendall's $\mathrm{T}>0.23$; Fig. II, Supplementary material). The linear regression analysis supported this general and positive relationship (Fig. $5 a)$, but user-specific models showed that it could be only partially ascribed to a causal link, as only three farming-oriented groups displayed significant models (Fig. 5b). Remarkably, local campesinos and farming corporations \& capitalized farmers in Argentina, the most widely distributed groups (PPT:PET ranges $>0.26$ ), showed non significant associations. Seasonality metrics showed a lower association with PPT:PET, being positive for the number of growing seasons, the peakness, and the browning rate, and negative for the greening-to-browning ratio.

-Insert Fig. 5 here-

\section{Discussion}

In the South American Dry Chaco and Chiquitania territory, the still dominant forests are rapidly being replaced by extensive croplands and pastures (Grau et al., 2005b; Killeen et al., 2007; Guyra Paraguay, 2013). Our study reveals that agriculture, typically associated to a homogeneous agribusiness system favoured by low land prices and a high profitability of commodities (Leguizamón, 2014), occurs and expands under a highly diverse array of social conditions (identified here as groups of agricultural land users). At present, large-scale corporations are intermingled across the territory with medium-scale capitalized farmers and 
ranchers, and partially capitalized smallholders (campesinos and indigenous), leading to contrasting landscapes and vegetation functional patterns. Within capitalized groups (individuals or corporations) and across the three countries, pasture production prevails under drier conditions, while pasture and crop production coexists under more humid conditions. Smallholders on the other hand seem to choose a diversified set of pasture and crop species even under more unfavorable climatic circumstances. On all groups, the preference for farming and/or ranching activities would arise from interacting endogenous and exogenous signals (market and climate), a variable accessibility to consumption, docking and transferring points, and the productive tradition of individuals or groups (van Dam, 2003; Grau et al., 2005a; Killeen et al., 2008; Leguizamón, 2014). Cultural or productive backgrounds and knowledge may be as important as market signals driving ecosystems' structure, as recently shown for Bolivian lowlands (Redo, 2013).

Surprisingly, the diverse management options followed by different groups were not associated with strong divergences in the primary productivity magnitude. Differences in paddock size (up to 60-fold contrast), cultivated species (annual vs. perennial, grasses vs. legumes, C3 vs. C4 photosynthetic syndromes), or level of mechanization, implied only a 1.2fold variation in mean NDVI. Small differences in the magnitude of productivity were only explained by the regional gradients of the climatic water availability (the higher the water availability, the higher the productivity), in concordance with previous assessments in natural vegetation in drylands (Jobbágy et al., 2002; Guerschman et al., 2003; Del Grosso et al., 2008). This climatic dependence, described as the most crucial factor for agricultural success in the region (Devani et al., 2007; Calviño and Monzón, 2009; Adámoli et al., 2011), demands further explorations, as it showed weak patterns when individual users were analyzed.

Contrary to what was found in relation to the variability of the magnitude of primary productivity, different groups showed strong differences in their seasonal and inter-annual behaviours (according to the ordination analysis, the first and second dimensions of divergence, respectively). Land use transitions would mostly imply changes on these functional attributes, as previous studies showed for the transition from grasslands and woodlands to agriculture (Guerschman et al., 2003; Volante et al., 2012). In terms of seasonality, although substantial variability exists within capitalized groups in Argentina and Bolivia, agriculture is based in the 
industrial production of soybean accompanied -in more humid areas or under irrigation practices- by a secondary cash crop (van Dam, 2003; Grau et al., 2005a). Thus, under these conditions, primary productivity resulted concentrated within short (one or two) growing periods with comparatively high greening and browning rates, and accompanied by lapses of low or null photosynthetic activity (i.e. a fallow). Interestingly, Andean indigenous colonists in Bolivia, with a limited access to technology and a different fate for their production (IFAD, 1998), converged with capitalized groups, achieving the highest frequency of NDVI peaks within a year. In Paraguay, the preference for herbaceous perennial species with similar phenological behaviours (C4 photosynthetic syndrome) (Glatzle and Stosiek, 2002) was related to a uniform and broad distribution of productivity within a single season.

Though several regional-scale studies on croplands, pastures, and grasslands showed that the inter-annual stability of primary production increases with decreasing aridity (Jobbágy et al., 2002; Verón et al., 2002; Guerschman et al., 2003), our study asserted this association exclusively on groups devoted to pasture production. In Paraguay, mixed ranching corporations and Mennonite colonists (under comparatively drier conditions) showed very high long term coefficient of variation values for the NDVI magnitude, while Brazilian corporations (under wetter conditions), showed very low ones. On the contrary, we found that in farming-oriented groups, particular management pathways entail exceptions to this biophysically-centred association, as farming corporations \& capitalized farmers in Argentina, under more humid conditions, showed a variable productivity across years, and local indigenous in Paraguay, under drier conditions, showed a low variation. Groups oriented to international markets constantly pursue a fine synchronization of sowing and harvesting dates (through different crops varieties) with climatic and market signals (Devani et al., 2007; Calviño and Monzón, 2009). The opposite occurs on groups that supply homestead to local markets, who necessary deal with a diversified and constant food demand, and may be less receptive to overseas signals that could homogenize their production. This positive relationship between diversity and stability could arise in time (i.e. different species grown in a single year), and space (different paddocks encompassed within a sample unit, i.e. a MODIS pixel), issues previously explored on cultivated and natural grasslands of Central and South America (Aragón et al., 2011; Ospina et al., 2012). 
In addition to the disparities in paddocks' spatial configuration, the observed divergences in temporal dynamics of primary productivity could lead to contrasting scenarios of related or subordinated ecosystem processes, services, and natural assets (Wallace, 2007). Due to the semiarid climate and very flat topography of the Dry Chaco and Chiquitania territory, land use could introduce changes in deep drainage and water tables dynamics (Nitsch, 1995; Jobbágy et al., 2008; Santoni et al., 2010). Likewise, a management that concentrates production in short periods of time may imply negative effects such as flooding and soil salinization due to a partial consumption of incoming rainfall water and higher deep drainage fluxes (Amdan et al., 2013; Giménez et al., in press). In terms of nature conservation, differences in the quality and intensity of interventions would interact with spatial configuration of paddocks in sustaining species diversity and cascading services (like pollination or pest control). Lightly intervened (physically and chemically, e.g. savanna-alike pasturelands in Paraguay) and/or complex agricultural landscapes (e.g. small paddocks intermingled with uncultivated vegetation in Bolivia) would favour diverse systems (Benton et al., 2003; Poggio et al., 2010). Interestingly, smallholder groups always led to heterogeneous landscapes, while under capitalized conditions, complexity depended on the time elapsed since deforestation and the compliance with land use planning laws (uncultivated corridors where frequent in Bolivia and Paraguay, but not in Argentina; Figure I, Supplementary material) (Adámoli et al., 2011). Finally, translating the primary productivity differences into crop or pasture yields remains to be a challenging task (Giménez et al., in press). Though feasible, the application of ecophysiological models to derive yields would require an extensive collection of field data encompassing the territory heterogeneity (Lobell et al., 2003). National statistics, extremely useful to explore regional pasture and crop production rates, would not allow comparisons across groups, as cross-national data at a sub-county scale is still lacking or inaccessible (Paruelo et al., 2004).

The combination of rural typology bibliography, high spatial resolution images, and remotely sensed spectral data allowed us to quantify the connections between landscape patterns, vegetation functioning, and agricultural land users. Nevertheless, we recognize three methodological aspects that could affect the precision and stability of our results. (i) Our typological approach, based on qualitative rather than quantitative delimitation variables, would not allow the isolation of the underlying mechanisms of divergences, like resource endowments. 
(ii) Each group explores a particular geographical space, and thus potentially particular climatic and soil conditions. By considering aridity effects on functioning, we assumed to encompass the main physical constrain to agriculture, however the strength of unconsidered variables on vegetation functioning remain to be explored. (iii) Some unmanaged variability within groups could be expected. As examples, in Argentina, campesinos can incorporate capitalistic elements in their production system (like GM crops) (Arza et al., 2012), while capitalized users encompass variable affluence and tenure conditions (e.g. familiar, corporate or private, private leasing in several forms). Mennonite colonists -due to different attitudes towards traditional values- have a different appropriation of technology, being complete in Paraguay, variable in Bolivia, and selective in Argentina (Cañás Bottos, 2008; GAMEO, 2013).

In our region, agricultural lands are currently home of a very diverse spectrum of farming and ranching groups, offering a singular possibility to assess the sensitive of structural and functional characteristics to variable management conditions. We found that groups of land users have a strong imprint on the configuration of landscapes and on the seasonal and interannual dynamics of primary productivity (but surprisingly not on its magnitude). Even so, the implications of these differences on future regional structural and functional characteristics would depend on group-specific expansion rates. In Argentina and Paraguay (comprising 62\% of the territory), dominance by capitalized farmers and ranchers seems to prevail under current political and economical contexts (Grau et al., 2005a; Vázquez, 2006; Leguizamón, 2014), implying increasingly larger holdings and less stable primary production. These groups, oriented to the production of commodities, could eventually choose to exchange the focus of their production from crops to pastures or viceversa following market signals (e.g. changes on soybean or meet international prices), with large implications on ecosystems' seasonal behaviour. Bolivia (38\% of the territory) offers a different perspective, as new agricultural land seems to be handled by a more diverse range of social groups -in response to local policieswith variable functional implications (Pacheco, 2006; Redo et al., 2011). Ultimately, these alternative and contrasting trajectories will have strong implications on future regional ecosystem processes (energy and carbon exchange with atmosphere), services (water regulation), and assets (biodiversity), and their spatial and temporal dynamics. 


\section{Acknowledgements}

This work was funded by grants from the International Research Development Center (IDRC-Canada, Project 106601-001), and the Inter-American Institute for Global Change Research (IAI, CRN II 2031), which is supported by the US National Science Foundation (Grant GEO-0452325). We would like to thank Albrecht Glatzle, Eva Florio, Jorge Mercau, Marcos Texeira, Raúl Giménez, and Roxana Aragón for their help during this study.

\section{References}

Adámoli, J., Guinzburg, R., Torrella, S., 2011. Escenarios productivos y ambientales del Chaco Argentino: 1977-2010. Fundación Producir Conservando, Buenos Aires, p. 101.

Allen, R.G., Pereira, L.S., Raes, D., Smith, M.D., 2004. Crop evapotranspiration. Guidelines for computing crop water requirements. FAO, Roma.

Amdan, M.L., Aragón, R., Jobbágy, E.G., Volante, J.N., Paruelo, J.M., 2013. Onset of deep drainage and salt mobilization following forest clearing and cultivation in the Chaco plains (Argentina). Water Resour Res 49, 6601-6612. Aragón, M.R., Oesterheld, M., Irisarri, G., Texeira, M., 2011. Grassland stability and diversity at the landscape scale. Landscape Ecol, 1011-1022.

Arístide, P., 2009. Procesos históricos de cambio en la apropiación del territorio de Figueroa (Santiago del Estero, Argentina, chaco semiárido). Universidad Internacional de Andalucía, Andalucía, Spain.

Arza, V., Goldberg, L., Vazquez, C., 2012. Argentina: Difusión del algodón GM e impacto en la rentabilidad de los pequeños productores de la Provincia del Chaco. Revista CEPAL 107, 137-156.

Baldi, G., Jobbágy, E.G., 2012. Land use in the dry subtropics: Vegetation composition and production across contrasting human contexts. J Arid Environ 76, 115-127.

Baldi, G., Verón, S.R., Jobbágy, E.G., 2013. The imprint of humans on landscape patterns and vegetation functioning in the dry subtropics. Glob Chang Biol 19, 441-458.

Benton, T.G., Vickery, J.A., Wilson, J.D., 2003. Farmland biodiversity: Is habitat heterogeneity the key? Trends Ecol Evol 18, 182-188.

Biondini, J.E., 2013. Colonia Menonita, http://www.coloniamenonita.com.ar/.

Biondini, M.E., Mielke Jr, P.W., Berry, K.J., 1988. Data-dependent permutation techniques for the analysis of ecological data. Vegetatio 75, 161-168.

Calviño, P., Monzón, J., 2009. Farming Systems of Argentina: Yield Constraints and Risk Management, in: Sadras, V., Calderini, D. (Eds.), Crop Physiology. Academic Press, San Diego, USA, pp. 55-70.

Cañás Bottos, L., 2008. Old Colony Mennonites in Argentina and Bolivia: Nation Making, Religious Conflict and Imagination of the Future. Brill, Leiden, Netherlands.

Casco Verna, G.E., 2011. Análisis del avance del uso agropecuario en el Dpto. de Alto Paraguay, entre los años 1997, 1999, 2002, 2004, 2005, 2008, 2009, 2010 y 2011. Dirección General de Gestión Ambiental (DGGA), Asunción, p. 12.

Clark, M.L., Aide, T.M., Grau, H.R., Riner, G., 2010. A scalable approach to mapping annual land cover at $250 \mathrm{~m}$ using MODIS time series data: A case study in the Dry Chaco ecoregion of South America. Remote Sens Environ 114, 28162832.

Conover, W.J., 1999. Practical Nonparametric Statistics. John Wiley and Sons, New York.

Consorcio L. Berger - ICASA, 2010. Planes de Ordenamiento Territorial 2011 - 2025. Municipios de Irala Fernandez, Filadelfia, Loma Plata, Mariscal Estigarribia. "Implementación Plan de Gestión Ambiental (PGA) del Programa Corredores de Integración de Occidente, Paquete I. Préstamo No. 1278/OC-PR (BID), Asunción.

Cotula, L., Vermeulen, S., Leonard, R., Keeley, J., 2009. Land grab or development opportunity? Agricultural investment and international land deals in Africa. IIED/FAO/IFAD, London/Roma. 
CRESUD, 2013. Página oficial CRESUD S.A., http://www.cresud.com.ar/.

Del Grosso, S., Parton, W., Stohlgren, T., Zheng, D., Bachelet, D., Prince, S., Hibbard, K., Olson, R., 2008. Global potential net primary production predicted from vegetation class, precipitation, and temperature. Ecology 89, 2117-2126. Devani, M.R., Ploper, L.D., Pérez, D., 2007. Producción de soja en el noroeste argentino. Agromercado 141, 21-28.

DGEEC, 2004. Atlas de las Comunidades Indígenas en el Paraguay. Dirección General de Estadística, Encuestas y Censos, Paraguay, Fernando de la Mora, Paraguay.

Eklundh, L., Jönsson, P., 2011. Timesat 3.1 Software Manual. Lund University, Lund, Sweden.

Ellis, E.C., Ramankutty, N., 2008. Putting people in the map: Anthropogenic biomes of the world. Front Ecol Environ 6, 439-447.

Ewel, J.J., 1999. Natural systems as models for the design of sustainable systems of land use. Agroforest Syst 45, 1-21. FENABOJA, 2013. Federación Nacional de Asociaciones Boliviano-Japonesas, http://www.fenaboja.com.

Fundación AGRECOL Andes, 2006. Desarrollo agropecuario sostenible en el Chaco Boliviano: problemas, tendencias, potenciales y experiencias, Cochabamba, Bolivia, p. 148.

GAMEO, 2013. Global Anabaptist Mennonite Encyclopedia Online.

Gasparri, N.I., Baldi, G., 2013. Regional patterns and controls of biomass in semiarid woodlands: lessons from the Northern Argentina Dry Chaco. Reg Environ Change 13, 1131-1144.

Gasparri, N.I., Grau, H.R., Manghi, E., 2008. Carbon pools and emissions from deforestation in extra-tropical forests of Northern Argentina between 1900 and 2005. Ecosystems 11, 1247-1261.

Giménez, R., Houspanossian, J., Mercau, J.L., Jobbágy, E.G., in press. Balancing agricultural and hydrological risk in farming systems of the Chaco plains. J Arid Environ.

Glatzle, A., 2004. Sistemas Productivos en el Chaco Central Paraguayo: Características, Particularidades. INTTAS, Loma Plata, Paraguay.

Glatzle, A., Stosiek, D., 2002. Country Pasture / Forage Resource Profile del Paraguay. Food and Agriculture Organization of the United Nations, Roma.

Grau, H.R., Aide, T.M., Gasparri, N.I., 2005a. Globalization and soybean expansion into semiarid ecosystems of Argentina. Ambio 34, 265-266.

Grau, H.R., Gasparri, N.I., Aide, T.M., 2005b. Agriculture expansion and deforestation in seasonally dry forests of northwest Argentina. Environ Conserv 32, 140-148.

Guerschman, J.P., Paruelo, J.M., Burke, I., 2003. Land use impacts on the normalized difference vegetation index in temperate Argentina. Ecol Appl 13, 616-628.

Guyra Paraguay, 2013. Monitoreo de los cambios de uso de la tierra, incendios e inundaciones Gran Chaco Americano. Guyra Paraguay, Asunción.

Houspanossian, J., Giménez, R., Mercau, J.L., Baldi, G., Jobbágy, E.G., Nosetto, M.D., in preparation. Farming South American Dry Forests: Current and potential deforestation as a function of agricultural suitability. J Arid Environ.

Houspanossian, J., Nosetto, M., Jobbágy, E.G., 2013. Radiation budget changes with dry forest clearing in temperate Argentina. Glob Chang Biol 19, 1211-1222.

Huang, C., Kim, S., Song, K., Townshend, J.R.G., Davis, P., Altstatt, A., Rodas, O., Yanosky, A., Clay, R., Tucker, C.J., Musinsky, J., 2009. Assessment of Paraguay's forest cover change using Landsat observations. Glob Planet Change 67, 1-12.

Huete, A., Didan, K., Miura, T., Rodriguez, E., 2002. Overview of the radiometric and biophysical performance of the MODIS Vegetation Indices. Remote Sens Environ 83, 195-213.

IFAD, 1998. Bolivia: Proyecto de Desarrollo y Consolidación de las Colonias de Pequeños Agricultores en el Departamento de Santa Cruz (PRODEPA). International Fund for Agricultural Development, Roma.

Jobbágy, E.G., Nosetto, M.D., Santoni, C.S., Baldi, G., 2008. El desafío ecohidrológico de las transiciones entre sistemas leñosos y herbáceos en la llanura chaco-pampeana. Ecología Austral 18, 305-322.

Jobbágy, E.G., Sala, O.E., Paruelo, J.M., 2002. Patterns and controls of primary production in the Patagonian steppe: a remote sensing approach. Ecology 83, 307-319.

Jönsson, P., Eklundh, L., 2002. Seasonality extraction by function fitting to time-series of satellite sensor data. IEEE T Geosci Remote 40, 1824-1832

Jönsson, P., Eklundh, L., 2004. TIMESAT - A program for analyzing time-series of satellite sensor data. Comput Geosci 30, 833-845. 
Killeen, T.J., Calderon, V., Soria, L., Quezada, B., Steininger, M.K., Harper, G., Solórzano, L.A., Tucker, C.J., 2007. Thirty Years of Land-cover Change in Bolivia. Ambio 36, 600-606.

Killeen, T.J., Guerra, A., Calzada, M., Correa, L., Calderon, V., Soria, L., Quezada, B., Steininger, M.K., 2008. Total historical land-use change in eastern Bolivia: Who, where, when, and how much? Ecol Soc 13, 36 [online].

Kleinpenning, J.M.G., 2009. The Mennonite Colonies in Paraguay. Origin and Development. Ibero-Amerikanisches Institut, Berlin.

Kostrowicki, J., 1992. A hierarchy of world types of agriculture, in: Mohammad, N. (Ed.), New Dimensions in Agricultural Geography: Historical dimensions of agriculture. Concept Publishing Company, Delhi, pp. 163-203.

Legendre, P., Legendre, L., 1998. Numerical ecology, 2 ed. Elsevier Science BV, Amsterdam.

Leguizamón, A., 2014. Modifying Argentina: GM soy and socio-environmental change. Geoforum 53, 149-160.

Lobell, D., Asner, G.P., Ortiz-Monasterio, J.I., Benning, T.L., 2003. Remote sensing of regional crop production in the Yaqui Valley, Mexico: estimates and uncertainties. Agric Ecosyst Environ 94, 205-220.

Lobell, D.B., Ortiz-Monasterio, J.I., Lee, A.S., 2010. Satellite evidence for yield growth opportunities in Northwest India. Field Crops Res 118, 13-20.

McGarigal, K., Marks, B., 1995. FRAGSTATS: Spatial analysis program for quantifying landscape structure. U.S. Department of Agriculture, Forest Service, Pacific Northwest Research Station, Portland.

MDA Federal, 2004. Landsat GeoCover 2000/ETM+ Edition Mosaics. USGS, Sioux Falls, USA.

Miles, L., Newton, A.C., DeFries, R.S., Ravilious, C., May, I., Blyth, S., Kapos, V., Gordon, J.E., 2006. A global overview of the conservation status of tropical dry forests. J Biogeogr 33, 491-505.

Monteith, J.L., 1981. Climatic variation and the growth of crops. Q J Roy Meteor Soc 107, 749-774.

Morello, J., Pengue, W., Rodríguez, A.F., 2005. Etapas de uso de los recursos y desmantelamiento de la biota del Chaco. Fronteras 4, 1-17.

Müller, R., Müller, D., Schierhorn, F., Gerold, G., Pacheco, P., 2012. Proximate causes of deforestation in the Bolivian lowlands: An analysis of spatial dynamics. Reg Environ Change 12, 445-459.

Nenadić, O., Greenacre, M., 2007. Correspondence Analysis in R, with two- and three-dimensional graphics: The ca package. J Stat Softw 20, 1-13.

New, M., Lister, D., Hulme, M., Makin, I., 2002. A high-resolution data set of surface climate over global land areas. Clim Res 21, 1-25.

Nitsch, M., 1995. El desmonte en el Chaco Central del Paraguay influencia sobre el agua subterránea y la salinización, 2ํㅗ Simposio sobre aguas subterráneas y perforación de pozos en el Paraguay, San Lorenzo, Paraguay, pp. 75-86.

Olson, D.M., Dinerstein, E., Wikramanayake, E.D., Burgess, N.D., Powell, G.V.N., Underwood, E.C., D'Amico, J.A., Itoua, I., Strand, H.E., Morrison, J.C., Loucks, C.J., Allnutt, T.F., Ricketts, T.H., Kura, Y., Lamoreux, J.F., Wettengel, W.W., Hedao, P., Kassem, K.R., 2001. Terrestrial ecoregions of the world: A new map of life on Earth. BioScience 51, 369-381.

Ospina, S., Rusch, G.M., Pezo, D., Casanoves, F., Sinclair, F.L., 2012. More stable productivity of semi natural grasslands than sown pastures in a seasonally dry climate. PLOS ONE 7, e35555.

Pacheco, P., 2006. Agricultural expansion and deforestation in lowland Bolivia: the import substitution versus the structural adjustment model. Land Use Policy 23, 205-225.

Paruelo, J.M., Guerschman, J.P., Baldi, G., Di Bella, C.M., 2004. La estimación de la superficie agrícola. Antecedentes y una propuesta metodológica. Interciencia 29, 421-427.

Paruelo, J.M., Jobbagy, E.G., Sala, O.E., 2001. Current distribution of ecosystem functional types in temperate South Amerca. Ecosystems 4, 683-698.

Paruelo, J.M., Lauenroth, W.K., 1995. Regional patterns of NDVI in North American shrublands and grasslands. Ecology 76, 1888-1898.

Pértile, V.C., 2003. Características sociales del pequeño productor del centro y sudoeste chaqueño a fines de los 90. Instituto de Geografía (IGUNNE), Resistencia, Argentina, pp. 265-292.

Poggio, S.L., Chaneton, E.J., Ghersa, C.M., 2010. Landscape complexity differentially affects alpha, beta, and gamma diversities of plants occurring in fencerows and crop fields. Biodivers Conserv 143, 2477-2486.

Portillo-Quintero, C.A., Sánchez-Azofeifa, G.A., 2010. Extent and conservation of tropical dry forests in the Americas. Biodivers Conserv 143, 144-155.

REDIEX, 2009. Atlas Geográfico del Chaco Paraguayo, Asunción, p. 52. 
Redo, D., 2013. The role of the individual producer in driving land change: The case of Santa Cruz, Bolivia, 1986-2006. GeoJournal 78, 69-84.

Redo, D., Millington, A.C., Hindery, D., 2011. Deforestation dynamics and policy changes in Bolivia's post-neoliberal era. Land Use Policy 28, 227-241.

Rueda, C.V., Baldi, G., Verón, S.R., Jobbágy, E.G., 2013. Apropiación humana de la producción primaria en el Chaco Seco. Ecología Austral 23, 44-54.

Santoni, C.S., Jobbágy, E.G., Contreras, S., 2010. Vadose zone transport in dry forests of central Argentina: Role of land use. Water Resour Res 46.

Scheinkerman de Obschatko, E., 2009. Las explotaciones agropecuarias familiares en la República Argentina: un análisis a partir de los datos del Censo Nacional Agropecuario 2002, Serie Estudios e Investigaciones. SAGPyA-IICA, Buenos Aires, p. 68.

UMSEF, 2008. Monitoreo de la superficie de bosque nativo de Argentina. Secretaria de Ambiente y Desarrollo Sustentable, Buenos Aires.

Unruh, J.D., 1997. The role of land conflict and land conflict resolution in a peace process: Mozambique's return to agriculture. Refuge 16, 28-33.

Vallejos, M., Bustamante, L., Volante, J., Vale, L., Ferreyra, E., Huykman, N., Arpigiani, D., Bonomo, I., Buchter, W., Campo López, G., Campos, C., García Collazo, A., Lauro, A., Lipera, M., Mosso, C., Newell, N., Recondo, V., Saucedo, J., Silvoso, C., Ueno, A., Urquiza, E., Paruelo., J., 2012. Descripción de la evolución de desmontes en la región del Chaco Semiárido Sudamericano, XXV Reunión Argentina de Ecología. ASAE, Luján.

van Dam, C., 2003. Cambio tecnológico, concentración de la propiedad y desarrollo sostenible: los efectos de la introducción del paquete soja/siembra directa en el Umbral al Chaco. Debate Agrario 35, 133-181.

Vázquez, F., 2006. Territorio y Población: nuevas dinámicas regionales en el Paraguay. Asociación Paraguaya de Estudios de Población, Asunción.

Vázquez, F., 2007. Las reconfiguraciones territoriales del Chaco paraguayo: Entre espacio nacional y espacio mundial. Observatorio de la Economía Latinoamericana 88, 1-17.

Verón, S.R., Paruelo, J.M., Sala, O.E., Lauenroth, W.K., 2002. Environmental controls of primary production in agricultural systems of the Argentine Pampas. Ecosystems 5, 625-635.

Volante, J.N., Alcaraz-Segura, D., Mosciaro, M.J., Viglizzo, E.F., Paruelo, J.M., 2012. Ecosystem functional changes associated with land clearing in NW Argentina. Agric Ecosyst Environ 154, 12-22

Wallace, K.J., 2007. Classification of ecosystem services: Problems and solutions. Biodivers Conserv 139, 235-246.

Whittaker, R.J., 1987. An application of Detrended Correspondence Analysis and Non-Metric Multidimensional scaling to the identification and analysis of environmental factor complexes and vegetation structures. J Ecol 75, 363-376.

\section{Tables}




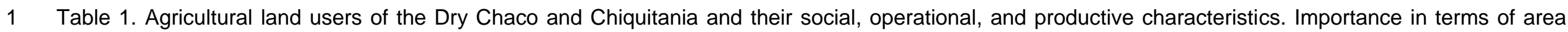

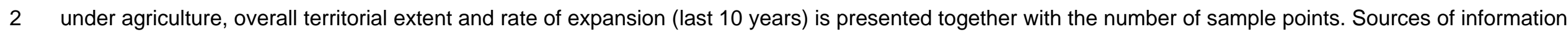



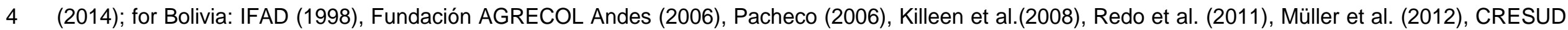

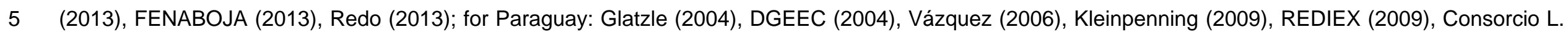

6 Berger - ICASA (2010), Casco Verna (2011).

\begin{tabular}{|c|c|c|c|c|c|c|c|c|c|c|c|}
\hline Country & Group & $\begin{array}{l}\text { Source of } \\
\text { capital }\end{array}$ & Cultivated species & $\begin{array}{l}\text { Production } \\
\text { fate }\end{array}$ & $\begin{array}{l}\text { Starting } \\
\text { period }\end{array}$ & $\begin{array}{l}\text { Fertilizers } \\
\& \\
\text { irrigation }\end{array}$ & $\begin{array}{l}\text { Mechaniz } \\
\text { ation }\end{array}$ & $\begin{array}{l}\text { Territorial } \\
\text { extent } \\
\left(\mathrm{km}^{2}\right)\end{array}$ & $\begin{array}{l}\text { Agricultur } \\
\text { al area } \\
\left(\mathrm{km}^{2}\right)\end{array}$ & $\begin{array}{l}\text { Rate of } \\
\text { increase } \\
\left(\mathrm{km}^{2} \mathrm{y}^{-1}\right)\end{array}$ & $\begin{array}{l}\text { Sampl } \\
\text { e } \\
\text { points }\end{array}$ \\
\hline \multirow[t]{3}{*}{ Argentina } & $\begin{array}{l}\text { Farming } \\
\text { corporations \& } \\
\text { capitalized } \\
\text { farmers }\end{array}$ & $\begin{array}{l}\text { Local and extra- } \\
\text { regional } \\
\text { Argentinean } \\
\text { investors }\end{array}$ & $\begin{array}{l}\text { Industrial and grain crops } \\
\text { (soybean, maize, cotton, wheat, } \\
\text { sunflower, sorghum) and } \\
\text { pastures }\end{array}$ & $\begin{array}{l}\text { International } \\
\text { market }\end{array}$ & $>1970$ & Low & High & $\begin{array}{l}\text { High } \\
(130,000)\end{array}$ & 50,000 & $\begin{array}{l}\text { High } \\
(1,000)\end{array}$ & \\
\hline & $\begin{array}{l}\text { Local campesinos } \\
\text { (smallholders) }\end{array}$ & Local & $\begin{array}{l}\text { Diversified (potato, pepper, } \\
\text { onion, watermelon, etc.) to } \\
\text { industrial crops (soybean, citrus, } \\
\text { rice, peanut) and pastures }\end{array}$ & Local market & $<1950$ & $\begin{array}{l}\text { None to } \\
\text { high }\end{array}$ & $\begin{array}{l}\text { Low to } \\
\text { medium }\end{array}$ & $\begin{array}{l}\text { High } \\
(>30,000)\end{array}$ & $\begin{array}{l}3,000- \\
13,000\end{array}$ & $\begin{array}{l}\text { Nil or } \\
\text { decreasin } \\
\mathrm{g}(?)\end{array}$ & 17 \\
\hline & $\begin{array}{l}\text { Mennonite } \\
\text { colonists }\end{array}$ & Local & $\begin{array}{l}\text { Industrial and grain crops } \\
\text { (maize, sunflower, sorghum) and } \\
\text { pastures }\end{array}$ & $\begin{array}{l}\text { Local to } \\
\text { national } \\
\text { market }\end{array}$ & 1990 & $\begin{array}{l}\text { Low (only } \\
\text { fertilizers) }\end{array}$ & $\begin{array}{l}\text { None to } \\
\text { low }\end{array}$ & Nil (?) & 100 & Nil (?) & 4 \\
\hline \multirow[t]{6}{*}{ Bolivia } & $\begin{array}{l}\text { Farming } \\
\text { corporations }\end{array}$ & $\begin{array}{l}\text { Bolivian, } \\
\text { Brazilian, and } \\
\text { Argentinean } \\
\text { investors }\end{array}$ & $\begin{array}{l}\text { Industrial and grain crops } \\
\text { (cotton, sugar cane, soybean, } \\
\text { maize, wheat, sorghum, } \\
\text { sunflower) and pastures }\end{array}$ & $\begin{array}{l}\text { International } \\
\text { market }\end{array}$ & 1990 & Unknown & High & $\begin{array}{l}\text { Medium } \\
(>7,500)\end{array}$ & 6,000 & $\begin{array}{l}\text { Medium } \\
(500)\end{array}$ & 23 \\
\hline & $\begin{array}{l}\text { Local (Cruceños) } \\
\text { farmers }\end{array}$ & Local & $\begin{array}{l}\text { Industrial and grain crops (sugar } \\
\text { cane, soybean, cotton, rice) and } \\
\text { pastures }\end{array}$ & $\begin{array}{l}\text { National to } \\
\text { international } \\
\text { market }\end{array}$ & $<1950$ & Unknown & High & $\begin{array}{l}\text { Medium } \\
(13,500)\end{array}$ & 10,500 & Low (300) & 13 \\
\hline & $\begin{array}{l}\text { Japanese } \\
\text { colonists }\end{array}$ & Local & $\begin{array}{l}\text { Industrial and grain crops } \\
\text { (soybean, sorghum, wheat, rice, } \\
\text { maize) and pastures }\end{array}$ & $\begin{array}{l}\text { National to } \\
\text { international } \\
\text { market }\end{array}$ & 1955 & Unknown & High & $\begin{array}{l}\text { Low } \\
(1,900)\end{array}$ & 1,600 & $\begin{array}{l}\text { Nil to low } \\
\text { (?) }\end{array}$ & 10 \\
\hline & $\begin{array}{l}\text { Andean } \\
\text { indigenous } \\
\text { colonists }\end{array}$ & Local & $\begin{array}{l}\text { Diversified (maize, rice, potato, } \\
\text { pepper, soybean, citrus, peanut) } \\
\text { and pastures }\end{array}$ & $\begin{array}{l}\text { Homestead to } \\
\text { national } \\
\text { market }\end{array}$ & $<1950$ & $\begin{array}{l}\text { Low to } \\
\text { medium }\end{array}$ & $\begin{array}{l}\text { None to } \\
\text { medium }\end{array}$ & $\begin{array}{l}\text { Medium } \\
(5,000)\end{array}$ & 3,500 & $\begin{array}{l}\text { Medium } \\
(650)\end{array}$ & 11 \\
\hline & $\begin{array}{l}\text { Local indigenous } \\
\text { (self-organized) }\end{array}$ & Local & $\begin{array}{l}\text { Diversified (tomato, watermelon, } \\
\text { peanut, etc.) }\end{array}$ & Homestead & $<1950$ & Unknown & Unknown & $\begin{array}{l}\text { Medium } \\
(7,000)\end{array}$ & 200 & Low (150) & 5 \\
\hline & Mennonite & Local & Industrial and grain crops & National to & 1960 & Unknown & High & Medium & 3,500 & Low (150) & 25 \\
\hline
\end{tabular}




\begin{tabular}{|c|c|c|c|c|c|c|c|c|c|c|c|}
\hline & colonists & & $\begin{array}{l}\text { (soybean, sorghum, maize, } \\
\text { sesame, cotton) and pastures }\end{array}$ & $\begin{array}{l}\text { international } \\
\text { market }\end{array}$ & & & & $(4,300)$ & & & \\
\hline \multirow[t]{5}{*}{ Paraguay } & $\begin{array}{l}\text { Brazilian ranching } \\
\text { corporations }\end{array}$ & Brazilian & $\begin{array}{l}\text { Herbaceous to savanna-alike } \\
\text { pastures (with remnant native } \\
\text { trees and shrubs) }\end{array}$ & $\begin{array}{l}\text { Brazilian } \\
\text { market }\end{array}$ & 1990 & None & Unknown & $\begin{array}{l}\text { Medium } \\
(4,850)\end{array}$ & 6,600 & $\begin{array}{l}\text { Medium } \\
(500)\end{array}$ & 19 \\
\hline & $\begin{array}{l}\text { Mixed ranching } \\
\text { corporations }\end{array}$ & $\begin{array}{l}\text { Capitalized } \\
\text { Mennonites and } \\
\text { extra-regional } \\
\text { investors } \\
\text { (Paraguayan, } \\
\text { Brazilian, } \\
\text { Argentinean, } \\
\text { Uruguayan, and } \\
\text { European) }\end{array}$ & $\begin{array}{l}\text { Herbaceous (Cenchrus ciliaris) } \\
\text { to savanna-alike pastures (with } \\
\text { remnant native trees and } \\
\text { shrubs) }\end{array}$ & $\begin{array}{l}\text { National to } \\
\text { international } \\
\text { market }\end{array}$ & 1990 & Unknown & $\begin{array}{l}\text { None to } \\
\text { medium }\end{array}$ & High (?) & 16,000 & $\begin{array}{l}\text { High } \\
(1,400)\end{array}$ & 25 \\
\hline & $\begin{array}{l}\text { Local campesinos } \\
\text { (smallholders) }\end{array}$ & Local & $\begin{array}{l}\text { Diversified (pulses, tubers, } \\
\text { pastures) }\end{array}$ & $\begin{array}{l}\text { Homestead to } \\
\text { local market }\end{array}$ & $<1950$ & Unknown & $\begin{array}{l}\text { None to } \\
\text { low }\end{array}$ & Nil (600) & $100 ?$ & $\begin{array}{l}\text { Unknown } \\
\text { (?) }\end{array}$ & - \\
\hline & $\begin{array}{l}\text { Local indigenous } \\
\text { (mission- } \\
\text { organized) }\end{array}$ & Local & $\begin{array}{l}\text { Diversified (beans, squash, } \\
\text { cassava, sweet potato, sesame, } \\
\text { maize, melon, watermelon) }\end{array}$ & $\begin{array}{l}\text { Homestead to } \\
\text { local market }\end{array}$ & $<1950$ & Unknown & None & $\begin{array}{l}\text { Low } \\
(3,700)\end{array}$ & 100 & Nil (?) & 16 \\
\hline & $\begin{array}{l}\text { Mennonite } \\
\text { colonists }\end{array}$ & Local & $\begin{array}{l}\text { Herbaceous (Panicum spp., } \\
\text { Cenchrus ciliaris) to savanna- } \\
\text { alike pastures (with remnant } \\
\text { native trees and shrubs and } \\
\text { Leucaena leucocephala) and } \\
\text { minor industrial and fodder } \\
\text { crops (cotton, sorghum, } \\
\text { safflower) }\end{array}$ & $\begin{array}{l}\text { National to } \\
\text { international } \\
\text { market }\end{array}$ & $<1950$ & None & High & $\begin{array}{l}\text { High } \\
(30,000)\end{array}$ & 11,000 & $\begin{array}{l}\text { Medium } \\
(125)\end{array}$ & 25 \\
\hline
\end{tabular}


7 Table 2. Description of the 19 functioning metrics depicting NDVI magnitude (metrics 1 to 3 ),

8 seasonality (4 to 12 , and 18 ), and inter-annual (13 to 17 ) and overall variability (19). Only

9 metrics 6 and 7 are calculated directly from Timesat v. 3.1. Metrics were based on Paruelo et al.

10 (2001), Jobbágy et al. (2002), and Eklundh and Jönsson (2011). Growing years are calculated

11 from September to August.

\begin{tabular}{|c|c|c|}
\hline & Metric & Description \\
\hline 1 & Mean & $\begin{array}{l}\text { Mean NDVI value. Calculated as the average of the } 2000-2011 \text { annual mean values (same } \\
\text { for metrics \#2 to \#12 but changing the focus annual value). }\end{array}$ \\
\hline 2 & Maximum & Maximum (annual) NDVI value. \\
\hline 3 & Minimum & Minimum (annual) NDVI value. \\
\hline 4 & Range & Difference between the (annual) maximum and minimum NDVI values. \\
\hline 5 & Intra-annual CV & Coefficient of variation of (annual) NDVI values. \\
\hline 6 & Greening & $\begin{array}{l}\text { Rate of increase of NDVI. Derivative of the NDVI ascent curve between } 0.2 \text { and } 0.8 \text { * } \\
\text { range. }\end{array}$ \\
\hline 7 & Browning & $\begin{array}{l}\text { Rate of decrease of NDVI. Derivative of the NDVI descent curve between } 0.8 \text { and } 0.2 \text { * } \\
\text { range. }\end{array}$ \\
\hline 8 & $\begin{array}{l}\text { Greening-to- } \\
\text { browning ratio }\end{array}$ & Measure of the asymmetry (skewness) of the NDVI curve. \\
\hline 9 & Growing period & $\begin{array}{l}\text { Length, in time (days), between the beginning to the end of the growing season, multiplied } \\
\text { by the number of growing seasons per year (metric \#11). Beginning and end are recorded } \\
\text { when the fitted NDVI curve crosses the minimum }+0.25 \text { *ange value within a single year. }\end{array}$ \\
\hline 10 & Peakness & Ratio of maximum NDVI to growing days metrics (\#2 and \#9) representing kurtosis. \\
\hline 11 & $\begin{array}{l}\text { Number of growing } \\
\text { seasons }\end{array}$ & $\begin{array}{l}\text { Number of growing seasons per year (i.e. number of crops per year). Only growing } \\
\text { seasons with range }>0.13 \text { were considered. }\end{array}$ \\
\hline 12 & Date of maximum & $\begin{array}{l}\text { Median date of the period above } 0.8 * \text { range }+ \text { minimum considering only the largest } \\
\text { growing season of the year. }\end{array}$ \\
\hline 13 & Long term mean CV & Inter-annual coefficient of variation of mean annual NDVI values. \\
\hline 14 & $\begin{array}{l}\text { Long term } \\
\text { maximum CV }\end{array}$ & Inter-annual coefficient of variation of maximum annual NDVI values. \\
\hline 15 & $\begin{array}{l}\text { Long term growing } \\
\text { period } \mathrm{CV}\end{array}$ & Inter-annual coefficient of variation of growing period. \\
\hline 16 & $\begin{array}{l}\text { Long term date of } \\
\text { maximum SD }\end{array}$ & Standard deviation of the date of maximum NDVI. \\
\hline 17 & Trend contribution & $\begin{array}{l}\text { Percentage of the overall variance of the NDVI time series explained by inter-annual } \\
\text { differences. }\end{array}$ \\
\hline 18 & $\begin{array}{l}\text { Seasonal } \\
\text { contribution }\end{array}$ & $\begin{array}{l}\text { Percentage of the overall variance of the NDVI time series explained by seasonal } \\
\text { differences. }\end{array}$ \\
\hline 19 & $\begin{array}{l}\text { Residual } \\
\text { contribution }\end{array}$ & Percentage of the overall variance of the NDVI time series unexplained by $\# 17$ and $\# 18$. \\
\hline
\end{tabular}



differences between groups according to Kruskal Wallis test $(p<0.001)$; for each metric, letters indicate significant differences between groups $(p<0.05)$.

\begin{tabular}{|c|c|c|c|c|c|c|c|c|c|c|c|c|c|}
\hline & & Argentina & & & Bolivia & & & & & Paraguay & & & \\
\hline & PPT:PET & 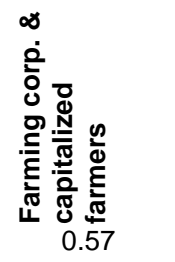 & 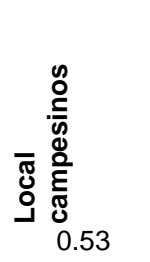 & 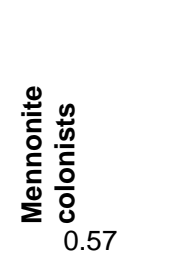 & 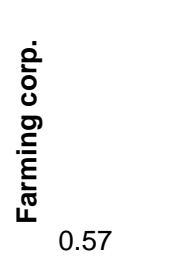 & 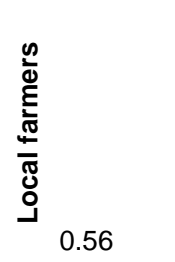 & 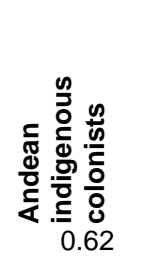 & 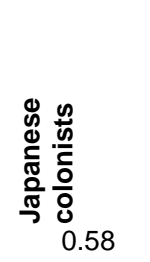 & 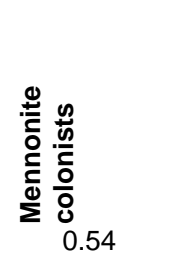 & 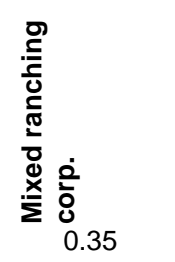 & 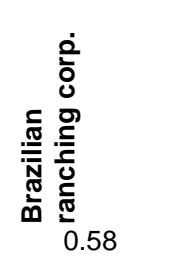 & 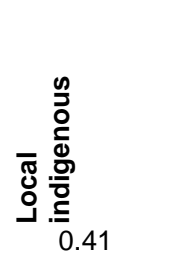 &  \\
\hline 1 & Mean & $\begin{array}{l}0.47 \pm \\
0.006^{\mathrm{ab}}\end{array}$ & $\begin{array}{c}0.49 \pm \\
0.009^{\mathrm{ab}}\end{array}$ & $\begin{array}{c}0.5 \pm \\
0.005^{\mathrm{ab}}\end{array}$ & $0.54 \pm 0.01^{\mathrm{c}}$ & $\begin{array}{l}0.56 \pm \\
0.008^{c}\end{array}$ & $\begin{array}{l}0.57 \pm \\
0.012^{c}\end{array}$ & $\begin{array}{l}0.56 \pm \\
0.012^{c}\end{array}$ & $0.49 \pm 0.01$ & $\begin{array}{l}0.46 \pm \\
0.008^{\mathrm{a}}\end{array}$ & $\begin{array}{l}0.57 \pm \\
0.006^{c}\end{array}$ & $\begin{array}{l}0.47 \pm \\
0.007^{\mathrm{a}}\end{array}$ & $\begin{array}{l}0.46 \pm \\
0.012^{\mathrm{ab}}\end{array}$ \\
\hline 2 & Maximum & $\begin{array}{l}0.83 \pm \\
0.018^{\text {gh }}\end{array}$ & $\begin{array}{c}0.7 \pm \\
0.021^{\mathrm{bc}}\end{array}$ & $\begin{array}{l}0.73 \pm \\
0.005^{\text {cde }}\end{array}$ & $\begin{array}{l}0.81 \pm \frac{t}{\mathrm{gh}} \\
0.012^{\mathrm{gh}}\end{array}$ & $\begin{array}{c}0.77 \pm \\
0.006^{\text {efgh }}\end{array}$ & $\begin{array}{c}0.86 \pm \\
0.009^{\text {defg }}\end{array}$ & $\begin{array}{l}0.79 \pm \\
0.018^{h}\end{array}$ & $\begin{array}{l}0.73 \pm \\
0.014^{\text {cd }}\end{array}$ & $\begin{array}{l}0.67 \pm \\
0.012^{\mathrm{ab}}\end{array}$ & $0.76 \pm \frac{ \pm}{\text { det }}$ & $0.64 \pm 0.01^{a}$ & $\begin{array}{l}0.69 \pm \\
0.016^{\mathrm{bc}}\end{array}$ \\
\hline 3 & Minimum & $\begin{array}{l}0.23 \pm \\
0.004^{\mathrm{a}}\end{array}$ & $0.29 \pm$ & $\begin{array}{l}0.28 \pm \\
0.005^{\text {cd }}\end{array}$ & $0.31 \pm$ & $0.33 \pm 0.01^{\dagger}$ & $\begin{array}{l}0.33 \pm \\
0.021^{\dagger}\end{array}$ & $\begin{array}{l}0.34 \pm \\
0.022^{\text {ef }}\end{array}$ & $\begin{array}{l}0.29 \pm \\
0.008^{\text {de }}\end{array}$ & $\begin{array}{l}0.26 \pm \\
0.004^{\mathrm{bc}}\end{array}$ & $0.32 \pm$ & $\begin{array}{c}0.28 \pm \\
0.005^{\text {cde }}\end{array}$ & $\begin{array}{l}0.25 \pm \\
0.006^{\mathrm{ab}}\end{array}$ \\
\hline 4 & Range & $0.61 \pm 0.02^{\dagger}$ & $0.41 \pm$ & $\begin{array}{c}0.45 \pm \\
0.005^{\text {cde }}\end{array}$ & $\begin{array}{l}0.5 \pm \\
0.018^{\mathrm{de}}\end{array}$ & $\begin{array}{c}0.44 \pm \\
0.012^{\text {bcde }}\end{array}$ & $\begin{array}{c}0.52 \pm \\
0.027^{\mathrm{bcd}}\end{array}$ & $\begin{array}{l}0.44 \pm \\
0.034^{\text {ef }}\end{array}$ & $\begin{array}{c}0.44 \pm \\
0.014^{\text {bcde }}\end{array}$ & $0.41 \pm$ & $0.44 \pm$ & $0.36 \pm 0.01^{a}$ & $\begin{array}{c}0.44 \pm \\
0.014^{\text {bcde }}\end{array}$ \\
\hline 5 & Intra-annual CV & $\begin{array}{l}0.44 \pm \\
0.016^{d}\end{array}$ & $0.29 \pm$ & $0.29 \pm 0^{c}$ & $\begin{array}{l}0.29 \pm \\
0.014^{c}\end{array}$ & $\begin{array}{l}0.25 \pm \\
0.012^{\mathrm{ab}}\end{array}$ & $\begin{array}{l}0.28 \pm \\
0.021^{\mathrm{ab}}\end{array}$ & $\begin{array}{l}0.25 \pm \\
0.025^{\mathrm{bc}}\end{array}$ & $\begin{array}{l}0.28 \pm \\
0.012^{\mathrm{bc}}\end{array}$ & $\begin{array}{l}0.29 \pm \\
0.004^{\frac{b}{b c}}\end{array}$ & $\begin{array}{l}0.24 \pm \\
0.004^{\mathrm{a}}\end{array}$ & $\begin{array}{l}0.24 \pm \\
0.005^{\mathrm{a}}\end{array}$ & $0.3 \pm 0.008^{\mathrm{c}}$ \\
\hline 6 & Greening & $\begin{array}{l}0.14 \pm \\
0.008^{\dagger}\end{array}$ & $\begin{array}{l}0.08 \pm \\
0.009^{\mathrm{ab}}\end{array}$ & $\begin{array}{l}0.09 \pm \\
0.005^{\mathrm{de}}\end{array}$ & $\begin{array}{c}0.09 \pm \\
0.006^{\text {bcde }}\end{array}$ & $\begin{array}{c}0.08 \pm \\
0.004^{\text {bcde }}\end{array}$ & $\begin{array}{c}0.11 \pm \\
0.006^{\mathrm{bcd}}\end{array}$ & $\begin{array}{l}0.09 \pm \\
0.009^{\text {ef }}\end{array}$ & $\begin{array}{l}0.08 \pm \\
0.004^{\mathrm{bc}}\end{array}$ & $\begin{array}{l}0.08 \pm \\
0.004^{\mathrm{bcd}}\end{array}$ & $0.09 \pm$ & $\begin{array}{l}0.06 \pm \\
0.002^{\mathrm{a}}\end{array}$ & $\begin{array}{l}0.09 \pm \\
0.004^{\mathrm{de}}\end{array}$ \\
\hline 7 & Browning & $\begin{array}{l}0.13 \pm \\
0.008^{\dagger}\end{array}$ & $\begin{array}{l}0.07 \pm \\
0.009^{\mathrm{cd}}\end{array}$ & $\begin{array}{l}0.06 \pm \\
0.005^{\mathrm{de}}\end{array}$ & $\begin{array}{l}0.1 \pm \\
0.008^{\text {ef }}\end{array}$ & $\begin{array}{c}0.07 \pm \\
0.006^{\text {cde }}\end{array}$ & $\begin{array}{c}0.11 \pm \\
0.009^{\text {cde }}\end{array}$ & $\begin{array}{l}0.09 \pm \\
0.015^{\mathrm{ef}}\end{array}$ & $\begin{array}{c}0.06 \pm \\
0.006^{\mathrm{bcd}}\end{array}$ & $\begin{array}{l}0.04 \pm \\
0.002^{\mathrm{ab}}\end{array}$ & $\begin{array}{l}0.05 \pm \\
0.002^{\mathrm{bc}}\end{array}$ & $0.04 \pm 0^{\mathrm{a}}$ & $\begin{array}{l}0.05 \pm \\
0.002^{\mathrm{cd}}\end{array}$ \\
\hline 8 & $\begin{array}{l}\text { Greening-to- } \\
\text { browing ratio }\end{array}$ & $\begin{array}{l}1.41 \pm \\
0.078^{\mathrm{ab}}\end{array}$ & $\begin{array}{l}1.39 \pm \\
0.07^{\mathrm{ab}}\end{array}$ & $\begin{array}{c}1.83^{ \pm} \pm \\
0.125^{\text {cde }}\end{array}$ & $\begin{array}{l}1.38 \pm \\
0.118^{\mathrm{a}}\end{array}$ & $\begin{array}{c}1.71 \pm \\
0.118^{\mathrm{abc}}\end{array}$ & $\begin{array}{c}1.28 \stackrel{ \pm}{ \pm} \\
0.099^{\mathrm{bcd}}\end{array}$ & $\begin{array}{l}1.44 \pm \\
0.202^{\mathrm{a}}\end{array}$ & $\begin{array}{c}1.65 \pm \\
0.096^{\mathrm{bcd}}\end{array}$ & $2.2 \pm 0.134^{\mathrm{e}}$ & $\begin{array}{l}2.26 \pm \\
0.112^{\mathrm{e}}\end{array}$ & $\begin{array}{l}1.89 \pm \frac{t}{\mathrm{de}} \\
0.115^{-1}\end{array}$ & $2.1 \pm 0.074^{e}$ \\
\hline 9 & Growing period & $\begin{array}{c}192.82 \pm \\
7.4^{\mathrm{a}}\end{array}$ & $\begin{array}{c}232.21 \pm \\
8.918^{\mathrm{bc}}\end{array}$ & $\begin{array}{c}206.68 \pm \\
7.825^{\mathrm{a}}\end{array}$ & $\begin{array}{c}219.27 \pm \\
7.94^{\mathrm{ab}}\end{array}$ & $\begin{array}{l}257.13 \pm \\
5.506^{\mathrm{bcd}}\end{array}$ & $\begin{array}{l}227.18 \pm \\
5.463^{\text {cde }}\end{array}$ & $\begin{array}{l}245.67 \pm \pm \\
9.644^{\mathrm{ab}}\end{array}$ & $\begin{array}{c}232.31 \pm \\
5.416^{\mathrm{b}}\end{array}$ & $\begin{array}{c}245.94 \pm \\
2.55^{\mathrm{bc}}\end{array}$ & $\begin{array}{l}278.17 \pm \\
2.762^{\mathrm{e}}\end{array}$ & $\begin{array}{l}266.08 \pm \\
3.01^{\mathrm{de}}\end{array}$ & $\begin{array}{r}239.21 \pm \\
5.96^{\mathrm{bc}}\end{array}$ \\
\hline 10 & Peakness & $3.29 \pm 0.09^{\dagger}$ & $\begin{array}{l}2.41 \pm \\
0.155^{\mathrm{bc}}\end{array}$ & $2.62 \pm$ & $\begin{array}{l}2.45 \pm \\
0.073^{\mathrm{def}}\end{array}$ & $\begin{array}{c}2.32 \pm \\
0.074^{\text {cde }}\end{array}$ & $\begin{array}{l}2.28 \pm \\
0.096^{\mathrm{bc}}\end{array}$ & $\begin{array}{l}2.13 \pm \\
0.142^{\mathrm{def}}\end{array}$ & $\begin{array}{l}2.43 \pm \\
0.076^{\mathrm{cd}}\end{array}$ & $\begin{array}{l}2.48 \pm \\
0.036^{b}\end{array}$ & $2.3 \pm 0.041^{b}$ & $\begin{array}{l}2.25 \pm \\
0.045^{a}\end{array}$ & $\begin{array}{l}2.76 \pm \\
0.064^{\mathrm{bc}}\end{array}$ \\
\hline 11 & $\begin{array}{l}\text { Number of growing } \\
\text { seasons }\end{array}$ & $\begin{array}{l}1.26 \pm \\
0.064^{\mathrm{de}}\end{array}$ & $\begin{array}{c}1.08 \pm \\
0.046^{\mathrm{bcd}}\end{array}$ & $0.95 \pm 0.03^{a}$ & $\begin{array}{l}1.28 \pm \\
0.075^{\mathrm{cde}}\end{array}$ & $\begin{array}{l}1.1 \pm \\
0.058^{\text {ef }}\end{array}$ & $\begin{array}{l}1.75 \pm \\
0.09^{\mathrm{abc}}\end{array}$ & $\begin{array}{l}1.49 \pm \\
0.145^{\dagger}\end{array}$ & $\begin{array}{l}1.14 \pm \\
0.06^{\mathrm{bcd}}\end{array}$ & $\begin{array}{l}0.99 \pm \\
0.006^{\mathrm{ab}}\end{array}$ & $1 \pm 0^{\mathrm{abc}}$ & $1 \pm 0^{\mathrm{abc}}$ & $1 \pm 0.004^{\mathrm{ab}}$ \\
\hline 12 & Date of maximum & $\begin{array}{l}54.12 \pm \\
0.284^{\text {cd }}\end{array}$ & $\begin{array}{l}52.84 \pm t \\
0.451^{\mathrm{cd}}\end{array}$ & $81 \pm 0.41^{\mathrm{e}}$ & $\begin{array}{l}53.16 \pm \\
0.385^{\mathrm{abcd}}\end{array}$ & $\begin{array}{l}52.68 \pm \\
0.202^{\mathrm{abc}}\end{array}$ & $\begin{array}{l}43.24 \pm \\
0.202^{\mathrm{bcd}}\end{array}$ & $\begin{array}{l}44.2 \pm \\
0.259^{\mathrm{ab}}\end{array}$ & $\begin{array}{l}58.6 \pm \\
0.192^{d}\end{array}$ & $\begin{array}{l}52.2 \pm \\
0.23^{\mathrm{bcd}}\end{array}$ & $\begin{array}{l}34.76 \pm \\
0.323^{\mathrm{a}}\end{array}$ & $\begin{array}{l}53.96 \pm \\
0.217^{\text {bcd }}\end{array}$ & $\begin{array}{l}57.96 \pm \frac{ \pm}{d} \\
0.174^{\frac{d}{2}}\end{array}$ \\
\hline 13 & $\begin{array}{l}\text { Long term mean } \\
\mathrm{CV}\end{array}$ & $\begin{array}{l}0.13 \pm \\
0.006^{\mathrm{ef}}\end{array}$ & $\begin{array}{c}0.11 \pm \\
0.009^{\text {bcde }}\end{array}$ & $0.13 \pm 0.01^{\dagger}$ & $\begin{array}{c}0.11 \pm \\
0.008^{\text {cdef }}\end{array}$ & $\begin{array}{c}0.09 \pm \\
0.004^{\mathrm{abcd}}\end{array}$ & $\begin{array}{l}0.09 \pm \\
0.006^{\mathrm{ab}}\end{array}$ & $\begin{array}{c}0.1 \pm \\
0.015^{\mathrm{abc}}\end{array}$ & $\begin{array}{c}0.11 \pm \\
0.008^{\text {cdef }}\end{array}$ & $\begin{array}{l}0.12 \pm \\
0.006^{\text {def }}\end{array}$ & $\begin{array}{l}0.08 \pm \\
0.006^{a}\end{array}$ & $\begin{array}{l}0.07 \pm \\
0.005^{a}\end{array}$ & $\begin{array}{l}0.12 \pm \\
0.006^{\text {def }}\end{array}$ \\
\hline 14 & $\begin{array}{l}\text { Long term } \\
\text { maximum CV }\end{array}$ & $\begin{array}{c}0.09 \pm \\
0.008^{\mathrm{bcd}}\end{array}$ & $\begin{array}{c}0.09 \pm \\
0.007^{\mathrm{bcd}}\end{array}$ & $\begin{array}{l}0.09 \pm \\
0.005^{\mathrm{cde}}\end{array}$ & $\begin{array}{l}0.08 \pm \\
0.006^{\mathrm{bc}}\end{array}$ & $\begin{array}{c}0.07 \pm \\
0.004^{\mathrm{bcd}}\end{array}$ & $\begin{array}{l}0.06 \pm \\
0.006^{\mathrm{ab}}\end{array}$ & $\begin{array}{l}0.1 \pm \\
0.018^{\mathrm{ab}}\end{array}$ & $\begin{array}{l}0.1 \pm \\
0.008^{\mathrm{cd}}\end{array}$ & $\begin{array}{l}0.12 \pm \\
0.006^{\mathrm{e}}\end{array}$ & $\begin{array}{l}0.06 \pm \\
0.006^{\mathrm{a}}\end{array}$ & $\begin{array}{c}0.08 \pm \\
0.005^{\mathrm{abc}}\end{array}$ & $\begin{array}{l}0.11 \pm \\
0.008^{\mathrm{de}}\end{array}$ \\
\hline
\end{tabular}




\begin{tabular}{|c|c|c|c|c|c|c|c|c|c|c|c|c|c|}
\hline 15 & $\begin{array}{l}\text { Long term growing } \\
\text { period CV }\end{array}$ & $\begin{array}{l}0.23 \pm \\
0.02^{\mathrm{dd}}\end{array}$ & $\begin{array}{l}0.19 \pm \\
0.012^{\mathrm{bc}}\end{array}$ & $\begin{array}{l}0.25 \pm \\
0.03^{\mathrm{de}}\end{array}$ & $0.31 \pm 0.02^{\mathrm{e}}$ & $\begin{array}{l}0.22 \pm \\
0.01^{\mathrm{cde}}\end{array}$ & $\begin{array}{l}0.24 \pm \\
0.021^{\text {cd }}\end{array}$ & $\begin{array}{l}0.25 \pm \\
0.025^{\text {cde }}\end{array}$ & $\begin{array}{l}0.24 \pm \\
0.016^{\mathrm{cd}}\end{array}$ & $\begin{array}{l}0.15 \pm \\
0.008^{\mathrm{ab}}\end{array}$ & $\begin{array}{l}0.14 \pm \\
0.011^{\mathrm{a}}\end{array}$ & $\begin{array}{l}0.16 \pm \\
0.01^{ \pm \frac{\mathrm{ab}}{\mathrm{b}}}\end{array}$ & $\begin{array}{l}0.24 \pm \\
0.016^{\mathrm{cd}}\end{array}$ \\
\hline 16 & $\begin{array}{l}\text { Long term date of } \\
\text { maximum SD }\end{array}$ & $\begin{array}{l}2.42 \pm \\
0.228^{\mathrm{ab}}\end{array}$ & $\begin{array}{l}3.13 \pm \\
0.392^{\mathrm{bcd}}\end{array}$ & $\begin{array}{l}3.81 \pm \\
0.505^{\mathrm{e}}\end{array}$ & $\begin{array}{l}2.54 \pm \\
0.236^{\mathrm{abc}}\end{array}$ & $\begin{array}{l}2.43 \pm \\
0.134^{\mathrm{cde}}\end{array}$ & $\begin{array}{l}2.13 \pm \\
0.491^{\mathrm{abc}}\end{array}$ & $\begin{array}{l}3.21 \pm \\
0.303^{\mathrm{a}}\end{array}$ & $\begin{array}{l}2.12 \pm \\
0.184^{\mathrm{a}}\end{array}$ & $\begin{array}{l}2.57 \pm \frac{ \pm}{2 \mathrm{abc}} \\
0.114^{\mathrm{acc}}\end{array}$ & $\begin{array}{l}3.12 \pm \\
0.165^{\text {cde }}\end{array}$ & $\begin{array}{l}2.46 \pm \\
0.137^{\mathrm{abc}}\end{array}$ & $\begin{array}{l}3.32 \pm \\
0.186^{\mathrm{de}}\end{array}$ \\
\hline 17 & Trend contribution & $\begin{array}{l}8.41 \pm \\
0.89^{\mathrm{ab}}\end{array}$ & $\begin{array}{l}14.93 \pm \pm \\
2.56^{\text {cdef }}\end{array}$ & $\begin{array}{c}13.96 \pm \\
1.48^{\dagger}\end{array}$ & $\begin{array}{l}11.97 \pm \\
1.22^{\text {bcdef }}\end{array}$ & $\begin{array}{l}9.89 \pm \\
0.89^{\text {abcdef }}\end{array}$ & $\begin{array}{l}8.29 \pm \\
1.12^{\mathrm{abcd}}\end{array}$ & $\begin{array}{l}11.52 \pm \\
1.99^{\mathrm{ab}}\end{array}$ & $\begin{array}{l}12.15 \pm \\
1.56^{\text {abcde }}\end{array}$ & $\begin{array}{l}13.8 \pm \\
1.10^{\mathrm{ef}}\end{array}$ & $\begin{array}{l}9.39 \pm \\
0.71^{\mathrm{abc}}\end{array}$ & $7.76 \pm 0.64^{\mathrm{a}}$ & $\begin{array}{l}13.1 \frac{ \pm}{\mathrm{def}} \\
1.15^{\frac{\mathrm{a}}{4}}\end{array}$ \\
\hline 18 & $\begin{array}{l}\text { Seasonal } \\
\text { contribution }\end{array}$ & $\begin{array}{l}61.9 \pm \\
2.91^{\mathrm{de}}\end{array}$ & $\begin{array}{l}57.75 \pm \\
3.59^{\mathrm{cd}}\end{array}$ & $\begin{array}{c}45.31 \pm \\
3.35^{\mathrm{a}}\end{array}$ & $\begin{array}{l}49.18 \pm \\
2.76^{\mathrm{ab}}\end{array}$ & $\begin{array}{l}58.32 \pm \\
1.87^{\mathrm{bcd}}\end{array}$ & $\begin{array}{l}54.01 \pm \\
3.41^{\mathrm{bcd}}\end{array}$ & $\begin{array}{l}57.57 \pm \\
3.18^{\text {abc }}\end{array}$ & $\begin{array}{l}62.4 \pm \\
2.34^{\mathrm{de}}\end{array}$ & $\begin{array}{l}62.16 \pm \\
1.48^{\mathrm{d}}\end{array}$ & $\begin{array}{l}64.95 \pm \\
1.69^{\mathrm{de}}\end{array}$ & $\begin{array}{l}68.35 \pm \\
1.29^{\mathrm{e}}\end{array}$ & $\begin{array}{l}54.17 \pm \\
2.10^{\mathrm{bc}}\end{array}$ \\
\hline 19 & $\begin{array}{l}\text { Residual } \\
\text { contribution }\end{array}$ & $\begin{array}{l}29.2 \pm \\
3.03^{\text {bcd }}\end{array}$ & $\begin{array}{l}25.89 \pm \\
2.94^{\mathrm{ab}}\end{array}$ & $\begin{array}{c}35.41 \pm \\
2.19^{\mathrm{ef}}\end{array}$ & $\begin{array}{l}37.98 \pm \\
2.39^{\mathrm{ef}}\end{array}$ & $\begin{array}{c}30.97 \pm \\
1.54 \mathrm{def}\end{array}$ & $\begin{array}{l}39.17 \pm t \\
2.94^{\text {cdef }}\end{array}$ & $\begin{array}{l}32.09 \pm \\
2.17^{\dagger}\end{array}$ & $\begin{array}{c}25.02 \pm \\
1.58^{\mathrm{bc}}\end{array}$ & $\begin{array}{c}20.18 \pm \\
1.10^{\mathrm{a}}\end{array}$ & $\begin{array}{c}23.16 \pm \\
1.40^{\mathrm{ab}}\end{array}$ & $\begin{array}{l}22.81 \pm \\
1.33^{\mathrm{ab}}\end{array}$ & $\begin{array}{l}30.6 \pm \\
1.50^{\text {cde }}\end{array}$ \\
\hline
\end{tabular}




\section{Figure captions}

Figure 1. Left panel in light gray, Dry Chaco and Chiquitania ecoregions (Olson et al., 2001) and in dark gray agricultural areas (crops and pastures) in March 2013. In the detailed maps, different symbols indicate sample sites of agricultural land users (cross-border groups have the same symbol, Table 1). Due to their reduced size, local indigenous samples in Bolivia were characterized only for their landscape patterns. White lines represent constant values of water availability (PPT:PET).

Figure 2. Paddock size (mean and largest values) across groups of agricultural land users in the Dry Chaco and Chiquitania. Letters represent the significances of differences among groups ( $p$ value $<0.05)$. Acronyms: AR Argentina, BO Bolivia, and PY Paraguay.

Figure 3. Seasonal patterns of the Normalized Difference Vegetation Index (NDVI) across groups of agricultural land users. Annual cycle is depicted from September 14 (Julian day 257) to August 29 (Julian day 241). Dotted lines indicate spatial (across sample points) standard error values.

Figure 4. (a) Reciprocal averaging (RA) ordination of sample points (light gray markers) according to the 19 functioning metrics (see Table 2). Axes I and II explained $34.0 \%$ and $21.2 \%$ of the inertia, respectively. Colour symbols indicate the average ordination values (centroid) for each group of agricultural land users within the three encompassed countries. The direction and relative length of the projection of the metrics (i.e. arrows) reveals the level of correlation with the axes. Main metrics are named inside the plot; others are named in the graphic reference. (bd) RA depicting all samples by country, and ellipses showing one standard deviation around the centroid of each group. Acronym: G:B greening-to-browning ratio.

Figure 5. Lineal regression models for the mean NDVI in relation to the precipitation-to-potential evapotranspiration ratio (PPT:PET). Different symbols and colours represent different agricultural land users; solid lines indicate significant models ( $p$-value $<0.05$ ). (a) Relationship 
46 considering all sample points together; (b) models considering all sample points within each 47 group. In (b), only groups with a significant model or a PPT:PET range $>0.2$ are named. 







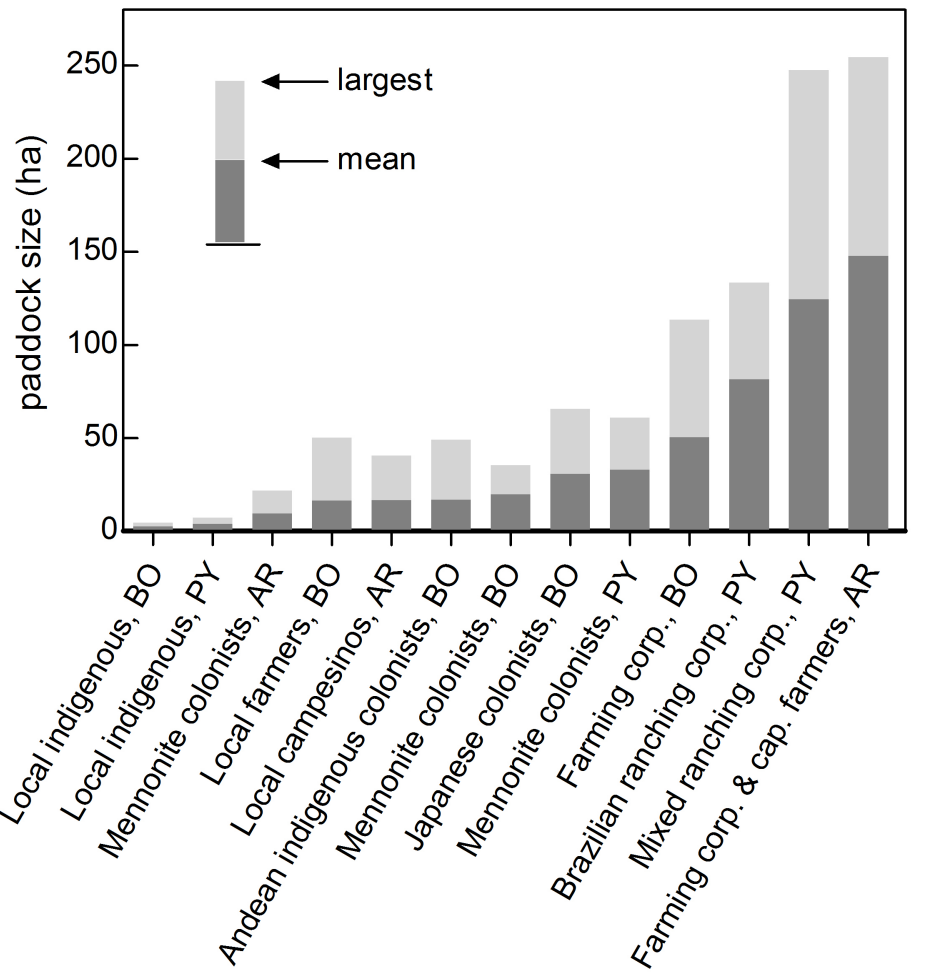



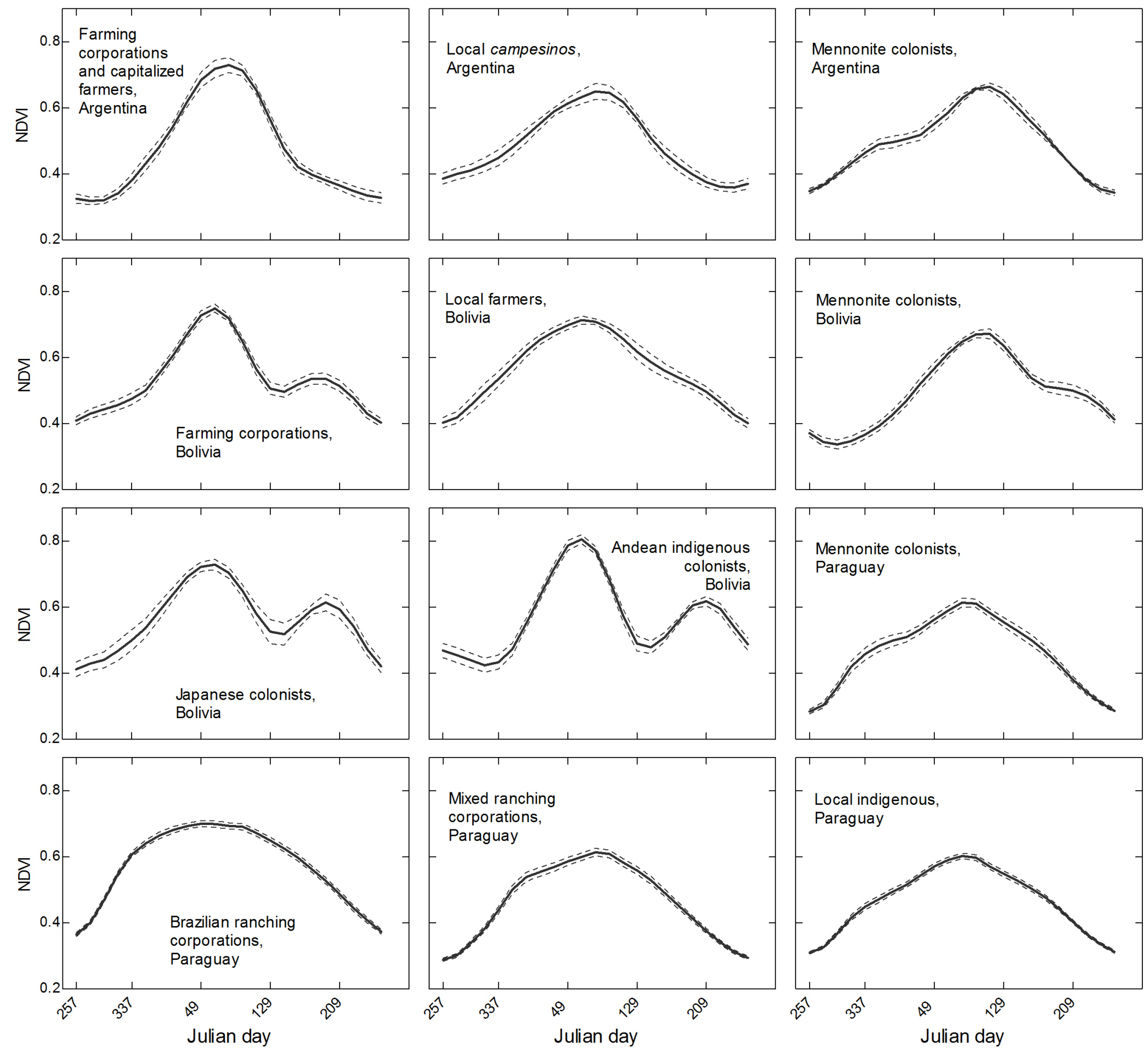


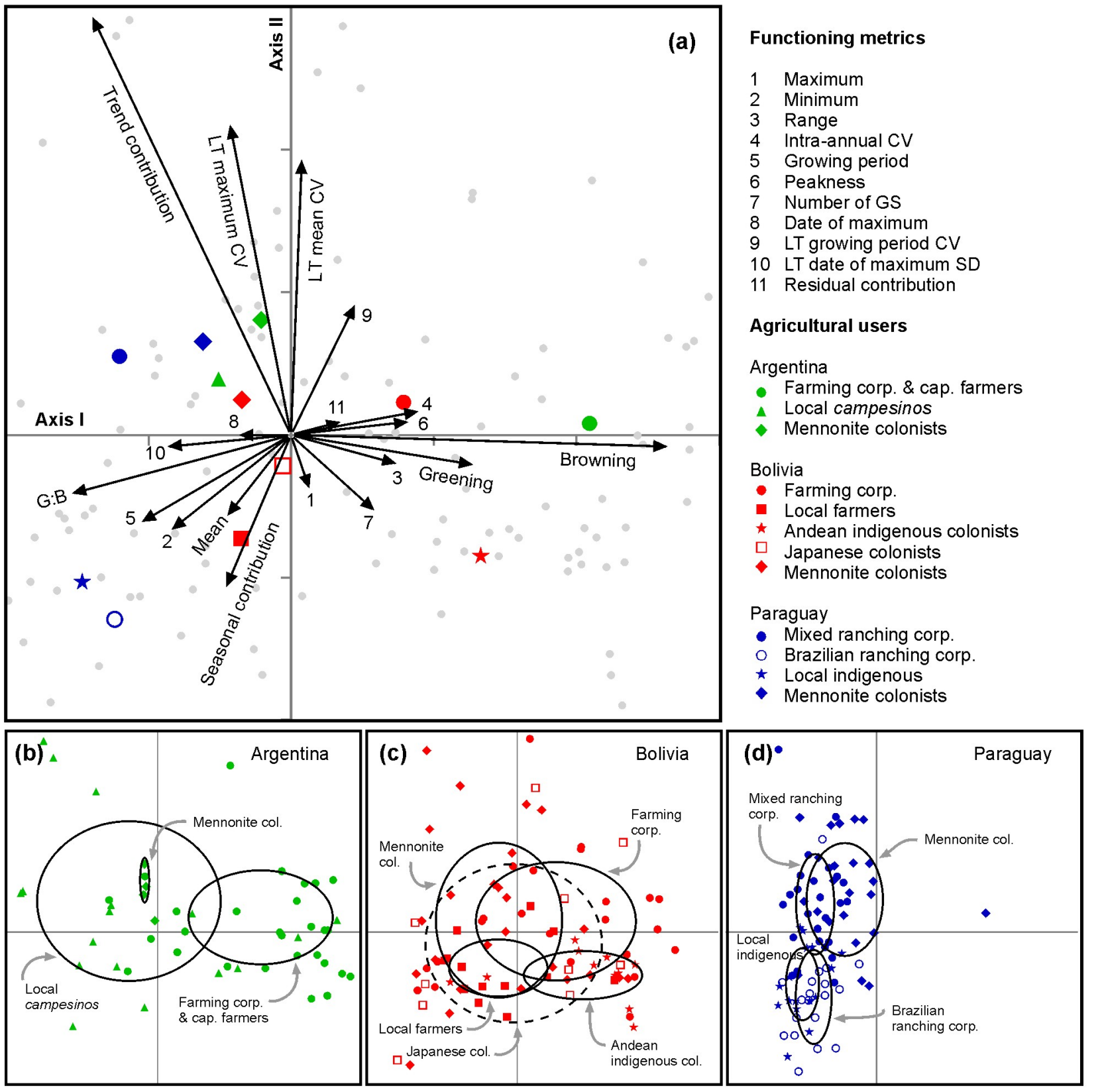




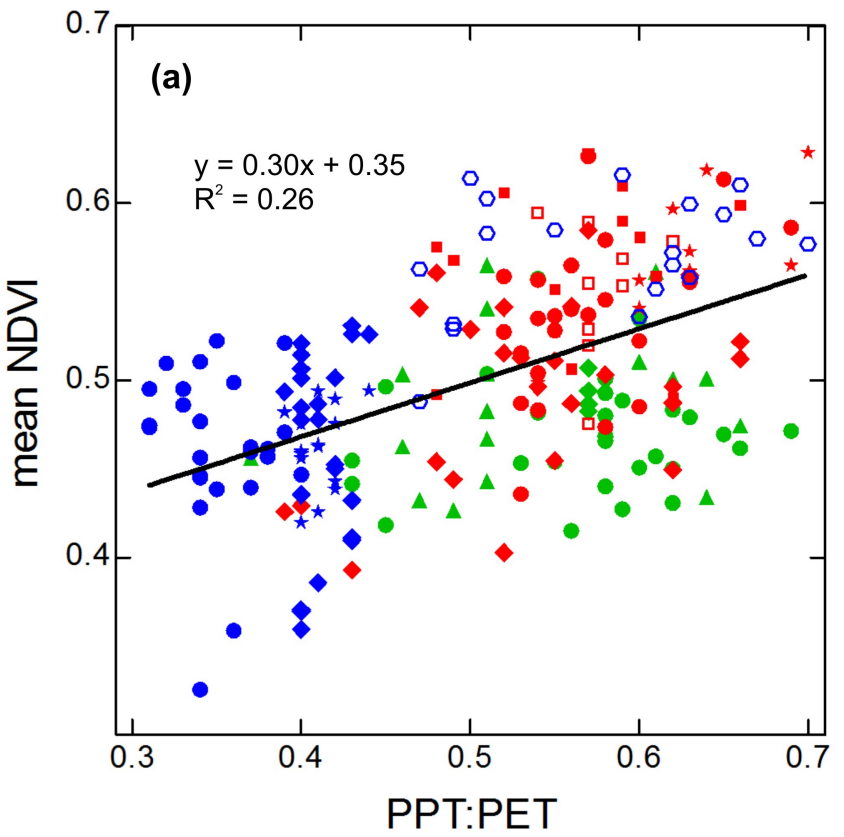

Argentina (-)

- Farming corp. \& cap. farmers

- Local campesinos

- Mennonite colonists

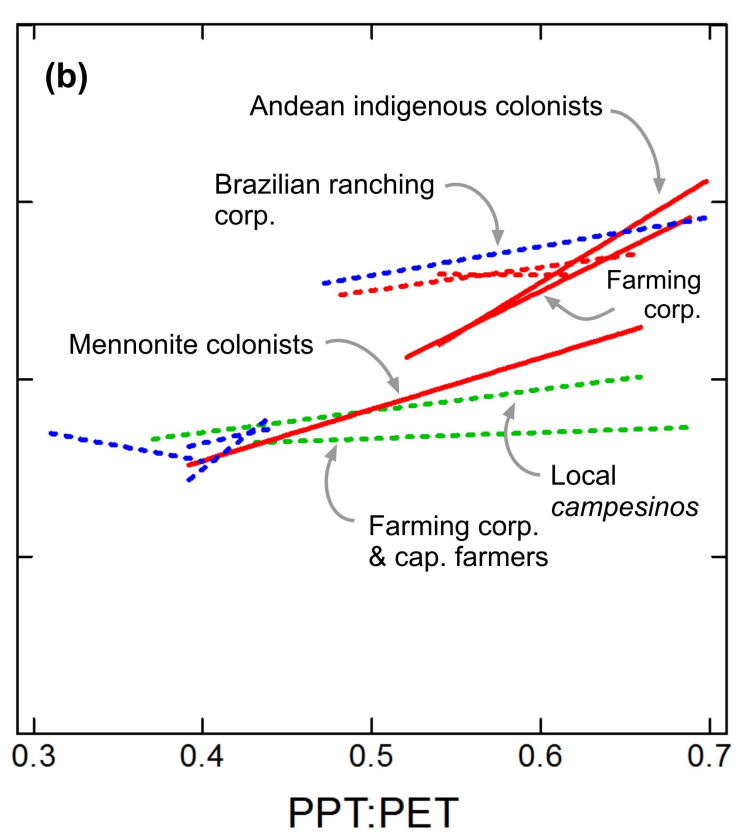

Bolivia (-)

- Farming corp.

- Local farmers

* Andean indigenous colonists

$\square$ Japanese colonists

- Mennonite colonists
Paraguay (-)

- Mixed ranching corp.

- Brazilian ranching corp.

$\star$ Local indigenous

- Mennonite colonists 
PPT:PET

RA I

RA II

Mean

Maximum

Minimum

Range

Intra-annual CV

Greening

Browning

Greening-to-browing ratio

Growing period

Peakness

Number of GS

Date of maximum

LT mean CV

LT maximum CV

LT growing period CV

LT date of maximum SD

Trend contribution

Seasonal contribution

Residual contribution

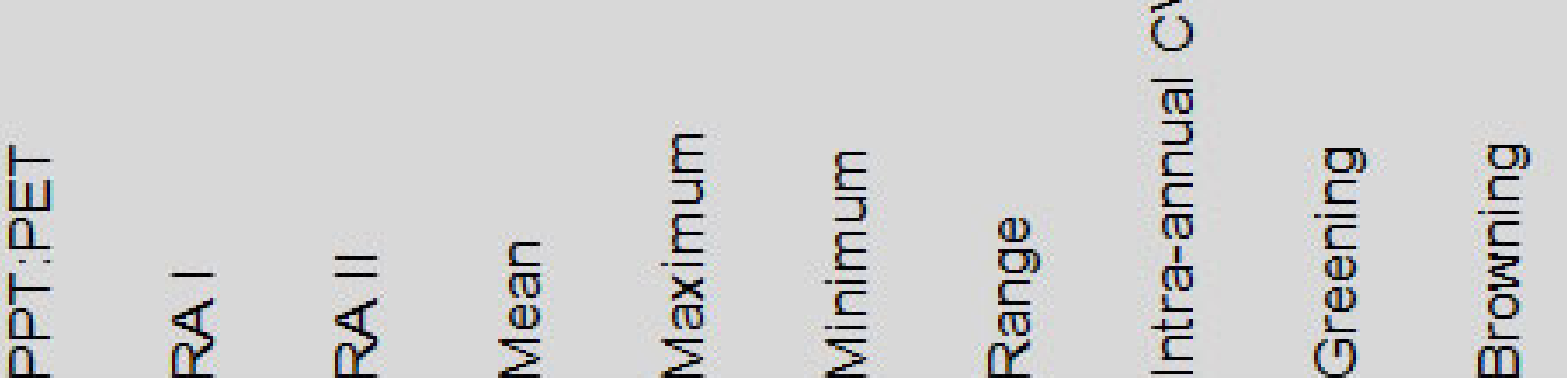

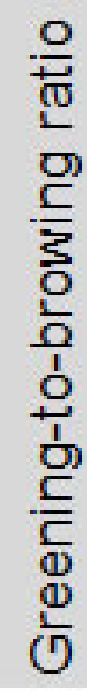



0.22

$-0.19 \quad 0.10$

$\begin{array}{llll}0.34 & -0.06 & -0.31\end{array}$

$\begin{array}{llll}0.41 & 0.53 & -0.12 & 0.37\end{array}$

$\begin{array}{llllll}0.23 & -0.32 & -0.27 & 0.61 & 0.06\end{array}$

$\begin{array}{lllllll}0.21 & 0.72 & 0.06 & 0.04 & 0.65 & -0.29\end{array}$

$\begin{array}{lllllll}-0.03 & 0.63 & 0.22 & -0.30 & 0.30 & -0.61 & 0.64\end{array}$

\begin{tabular}{llllllll|l}
0.14 & 0.52 & 0.04 & 0.03 & 0.51 & -0.27 & 0.66 & 0.53
\end{tabular}

$\begin{array}{lllllllll}0.29 & 0.80 & 0.09 & 0.03 & 0.58 & -0.22 & 0.68 & 0.53 & 0.52\end{array}$

$\begin{array}{llllllllll}-0.27 & -0.44 & -0.05 & 0.03 & -0.25 & 0.09 & -0.26 & -0.23 & -0.02 & -0.45\end{array}$

$\begin{array}{llllllllllll}-0.05 & -0.58 & -0.30 & 0.28 & -0.26 & 0.36 & -0.43 & -0.55 & -0.32 & -0.47 & 0.34\end{array}$

$\begin{array}{lllllllllllll}0.24 & 0.68 & 0.15 & 0.03 & 0.58 & -0.16 & 0.64 & 0.51 & 0.48 & 0.63 & -0.31 & -0.67\end{array}$

$\begin{array}{lllllllllllll}0.31 & 0.45 & -0.13 & 0.10 & 0.44 & -0.07 & 0.40 & 0.27 & 0.40 & 0.47 & -0.43 & -0.23 & 0.31\end{array}$

$\begin{array}{llllllllllllll}-0.12 & 0.01 & 0.22 & -0.23 & -0.16 & -0.16 & -0.05 & 0.07 & -0.16 & 0.02 & -0.13 & -0.11 & -0.02 & -0.20\end{array}$

$\begin{array}{lllllllllllllll}-0.08 & 0.19 & 0.67 & -0.23 & 0.05 & -0.29 & 0.22 & 0.33 & 0.22 & 0.21 & -0.06 & -0.30 & 0.23 & 0.02 & 0.14\end{array}$

$\begin{array}{llllllllllllllll}-0.26 & 0.05 & 0.55 & -0.43 & -0.23 & -0.35 & 0.00 & 0.22 & 0.01 & 0.02 & -0.03 & -0.26 & 0.05 & -0.08 & 0.17 & 0.35\end{array}$

$\begin{array}{lllllllllllllllll}0.11 & 0.32 & 0.25 & 0.03 & 0.18 & 0.00 & 0.19 & 0.14 & 0.12 & 0.29 & -0.21 & -0.36 & 0.36 & 0.15 & 0.05 & 0.14 & 0.16\end{array}$

$\begin{array}{llllllllllllllllll}-0.07 & -0.15 & 0.03 & 0.11 & -0.06 & 0.06 & -0.05 & -0.11 & 0.03 & -0.05 & 0.16 & 0.17 & -0.10 & -0.15 & -0.03 & -0.04 & 0.00 & 0.03\end{array}$

$\begin{array}{lllllllllllllllllll}-0.11 & -0.20 & 0.54 & -0.03 & -0.18 & 0.07 & -0.15 & -0.11 & -0.12 & -0.12 & 0.13 & 0.03 & -0.07 & -0.25 & 0.10 & 0.51 & 0.21 & 0.05 & 0.10\end{array}$

$\begin{array}{llllllllllllllllllll}-0.05 & -0.09 & -0.40 & -0.09 & -0.10 & -0.05 & -0.08 & -0.01 & -0.10 & -0.13 & 0.03 & 0.15 & -0.18 & 0.00 & -0.05 & -0.27 & -0.18 & -0.35 & -0.23 & -0.36\end{array}$



